\title{
Creditor rights and corporate risk-taking
}

\author{
Viral V. Acharya \\ London Business School and CEPR \\ vacharya@1ondon.edu \\ Yakov Amihud* \\ New York University \\ yamihud@stern.nyu.edu \\ Lubomir Litov \\ Washington University in St. Louis \\ litov@wustl.edu
}

6 February, 2008

\begin{abstract}
We propose that stronger creditor rights in bankruptcy reduce corporate risk-taking. Employing country-level data, we find that strong creditor rights are associated with a greater propensity of firms to engage in diversifying mergers, and this propensity changes in response to changes in the country creditor rights. Also, in countries with stronger creditor rights companies' operating risk is lower, and acquirers with low-recovery assets prefer targets with high-recovery assets. These relationships are strongest in countries where management is dismissed in reorganization, suggesting an agency-cost effect. Our results suggest that there might be a "dark" side to strong creditor rights in that they can induce costly risk avoidance in corporate policies. Thus, stronger creditor rights may not necessarily be optimal.

* Ira Leon Rennert professor of finance.

We acknowledge with thanks comments and suggestions that helped improve the paper by Barry Adler, Kenneth Ahern, Heitor Almeida, Moshe Barniv, Sid Chib, Phil Dybvig, Mike Faulkender, Radha Gopalan, Todd Gormley, Bill Greene, Kose John, Ohad Kadan, Todd Milbourn, Holger Mueller, Troy Paredes, Antoinette Schoar, Alan Schwartz, Anjan Thakor, Daniel Wolfenzon, Jeff Wurgler, Bernie Yeung, the seminar participants at Washington University in Saint Louis, and the seminar participants at the Salomon Center corporate governance seminar of New York University and at the University of Michigan. We thank Simeon Djankov, Caralee McLeish for providing access to their creditor rights data. Rong Leng provided excellent research assistance.
\end{abstract}




\section{Introduction}

Stronger creditor rights are generally considered a good thing. They may expand the financing capacity of the firm by limiting the ability of owners to expropriate firm's value, thus reducing the costs that result from the conflict of interests between owners and providers of debt capital. ${ }^{1}$ This paper proposes that strong creditor rights may also have a "dark side" in that they affect the corporate investment policy: stronger creditor rights induce firms to engage in risk-reducing, potentially inefficient, investments. Strong creditor rights in default may also cause inefficient liquidations that extinguish the continuation option of firm's enterprise and impose private costs on managers if these rights mandate the replacement of management. To avoid these costs, shareholders and management reduce the likelihood of distress by cutting down on risk-taking activities, for example, by diversifying or reducing operating risk, actions that that would otherwise not be undertaken. We provide cross-country as well as within-country empirical evidence in support of this thesis.

Our empirical evidence employs three different measures of corporate risk-taking whose variation across countries we seek to explain. We find the following:

(1) Creditor rights affect the nature of mergers and acquisitions (M\&A) activity whether it is focusing or diversifying across industries. Stronger creditor rights in a country are associated with a greater propensity to do diversifying mergers. Furthermore, changes in a country's creditor rights affect the M\&A activity in a similar direction: the extent diversification increases following the strengthening of creditor rights and declines if they are weakened.

(2) In countries with stronger creditor rights, there is a lower level of operating risk, measured by the standard deviation of firms' ROA.

\footnotetext{
${ }^{1}$ Stockholders can expropriate value by diversion of cashflow or by risk shifting (Jensen and Meckling (1976)). The latter means that when the firm approaches default, stockholders are induced to take on excessive risk which result in shifting value from creditors to stockholders.
} 
Overall, these results are strongest (statistically as well as economically) for the creditor rights corresponding to whether there is no automatic stay on secured creditors (AUTOSTAY) and whether management is replaced in bankruptcy (MANAGES). For example, MANAGES affects the likelihood of a merger being in the same industry by $6.6 \%$ (based on Table 3) where the standard deviation of this likelihood across countries is $10.3 \%$. Similarly, MANAGES lowers the operating risk measured at the country level by around 3\% (based on Table 8 ) where the cross-country standard deviation of operating risk is $2 \%$. Thus, the effect of creditor rights on corporate investment policy seems reasonably large.

Since countries differ in the composition of their industries, and since the propensity to diversify or reduce risk may differ across industries, we test the relationship between creditor rights and diversifying mergers after controlling for the industry effect following the methodology of Rajan and Zingales (1998). We find that after controlling for the industry effect, the findings in (1) and (2) above still hold.

(3) In countries with strong creditor rights, target firms whose assets have high recovery value in default (or distress) are more likely to be acquired by firms whose assets have low recovery value. This is because high recovery value of assets may enable firms in distress to defer default by liquidating some of these assets and using the proceeds to service the debt. Thus, by acquiring a highrecovery target, a low-recovery firm reduces the likelihood of default in case of distress.

Our analysis focuses on M\&As since they provide a unique opportunity to observe the type of a major corporate investment and its potential effect on corporate risk - whether the acquisition is diversifying (across industries) or focusing (within-industry). Diversifying M\&As create firms whose revenue is not concentrated in a few business segments (pertaining to different industries). Such firms have been found to have significantly lower idiosyncratic risk (Comment and Jarrell (1995)). Diversifying conglomerate mergers are found by Amihud and Lev (1981) to be associated with managerial motivation to reduce risk. In M\&As, we can also identify clearly the nature 
of the assets in which the company is investing - whether they have high or low recovery value. Also important, especially for our setting, corporate investment in the form of M\&A is not tainted by cross-country differences in accounting and disclosure practices that affect other measures of investment such as capital expenditures and R\&D. However, we recognize that firms employ other, likely difficult to observe, means to reduce risks, and therefore we also analyze the overall operating risk of firms.

Our paper is related to both the literature on diversification by firms and on the effect of claimholder rights in a country on firm's investment and financial choices. Managerial interests are shown to affect both investment and financing choices by firms. Amihud and Lev (1981) and Aggarwal and Samwick, 2003 suggest that managerial agency problem - aversion to risk or private benefits due to empire building - leads to conglomeration. Our paper suggests that managers may be averse to risk - and consequently diversify and reduce operating risk - because of the private cost in case of default. Gilson (1989) documents that following severe decline in stock performance, firms with leverage are almost thrice as likely to fire top-level management compared to firms that are not distressed. Importantly, the laid-off managers are not employed in publicly listed companies for another three years, implying that managers of distressed firms suffer significant private cost. Gilson suggests that this cost may induce managers to employ risk-reducing policies such as diversifying mergers and favoring less risky investments. Gilson also finds that a substantial portion of managerial layoff upon distress is due to direct intervention by bank lenders, a finding that is more recently supported by Ozelge (2007). Baird and Rassmussen (2006) too highlight the role of lenders in affecting changes the firm's management, including board members. Eckbo and Thornburn (2003) find that in Sweden, where bankruptcy filing automatically terminates the manager's employment, managers incur large loss of private benefits of control, which induces them to invest conservatively.

Throughout the paper, exploit as explanatory variable the variation of creditor rights across countries in their bankruptcy codes. Djankov et al. (2007a) show evidence that creditor rights have changed little between late 1970s and early 1990s, the beginning of our dataset. Therefore, we can consider creditor rights in a country to be a function of its legal origin and largely exogenous to the nature of the country's overall corporate 
investment. Even the few creditor right changes within a country, whose effects we analyze, are often motivated by exogenous forces such as promoting employment, recovering from crises, transition from socialist to capitalist regimes, among others.

The impact of creditor rights on investment policy is examined in a number of recent studies. Manso (2005) and Landier (2006) focus theoretically on the de-motivating effect on innovation and entrepreneurship of tough outcomes for entrepreneurs upon failure (strong creditor rights, being an example). Acharya and Subramanian (2007) embed the choice of leverage as well as innovation in a theoretical setting and also show empirically that strong creditor rights bear significantly negatively on corporate innovation, measured by the intensity of patent creation and citation by firms. While their evidence is based on cross-country and time-series analysis, Chava and Roberts (2008) and Nini, Smith and Sufi (2006) consider the effect on firm-level investments of creditor rights, exploiting the within-US variation in the form of covenants and capital expenditure restrictions explicitly contained in debt contracts.

Creditor rights and their enforcement are shown to affect the extent of debt financing. Djankov, McLeish, and Shleifer (2007a, 2007b) document that creditor rights such as MANAGES and AUTOSTAY are associated with higher aggregate lending, in the cross-section of countries as well as in time-series around creditor rights changes. Haselmann, Pistor and Vig (2006) study lending in Central and East European countries and find that it is the improvement in enforcement of creditor rights, for example, due to the creation of a collateral registry, that boosts lending rather than an increase in creditor rights such as MANAGES and AUTOSTAY. This literature mostly focuses on financing choices, taking as given the investment choices of firms. Our paper argues that investment choices of firms also respond to creditor rights. Adler (1992) suggests that while strong creditor rights induce the manager to increase the firm's risk as the firm approaches default, their ex-ante effect is to reduce risk and avoid insolvency. Our model directly analyzes the propensity of stockholders to take risks and shows the tradeoffs, given creditor rights.

Finally, another set of complementary papers examines legal institutions other than creditor rights in bankruptcy. Rossi and Volpin (2004) document that strong shareholder rights play an important role in determining the volume and number of 
mergers and acquisitions across countries. John, Litov and Yeung (2007) show evidence that investor protection is an important determinant of the risk-taking incentives of corporate insiders.

The outline of the paper is as follows. Section 2 presents a model of the causal effect of creditor rights on corporate investment choice. Section 3 discusses the data and empirical design and presents the results. Section 4 offers concluding remarks.

\section{Model}

We present a stylized model to analyze the effect of creditor rights on firm's risktaking incentives. In particular, the model examines the effect of reorganization outcomes for management and shareholders of a distressed firm on the ex-ante investments of the firm. The time-line of the model is presented in Figure 1.

\section{INSERT FIGURE 1 HERE.}

Consider a firm at date 0 that is run by an owner/entrepreneur (the "manager" of the firm). The firm has made some past investment (say $I$ units) and has some existing debt in place of face value $F$ which is maturing at date $1 .{ }^{2}$ The manager can choose at date 0 the risk of the firm's future cash flows to be realized from this investment at date 1. We adopt the technology for choice of risk from a part of the banking literature, starting with the models of Blum $(1999,2002)$ and Allen and Gale (2000). The risk choices at date 0 are indexed by $y \geq 0$, which represents the firm's cash flow in case the investment succeeds at date 1 . Success is likely with probability $p(y)$, where $0<p(y)<1$, $p^{\prime}(y)<0$, and $p^{\prime \prime}(y)<0$. With remaining likelihood, $[1-p(y)]$, the investment fails at date 1 and produces cash flow of zero. Thus, $y$ is also an index for the risk of default of the firm: Greater $y$ reduces the likelihood of success $p(y)$ (in a concave fashion). Agents are risk-neutral and the risk-free rate of interest is zero.

\footnotetext{
${ }^{2}$ We do not model the choice of leverage and its benefits and costs. Our empirical tests will, however, control for potential endogeneity of leverage to creditor rights. Acharya, Sundaram and John (2004) provide a theoretical and empirical analysis of how leverage responds to creditor rights in a cross-country setting.
} 
At date 0 , the owner/manager makes the choice of risk, maximizing equity value net of creditor payments, and anticipating the outcomes from resolution of distress (if any) at date 1 .

In case of default at date 1, the continuation prospects of the firm depend upon managerial quality. Managerial ability at date 1 may be either high or low with equal probabilities. We assume that neither the firm nor the manager know this ability unless it is investigated at date 1 , as we explain below. Also, for simplicity, we assume that managerial ability does not affect the date-0 investment. In other words, managers are assumed to be randomly endowed at date 1 to be high or low type with equal likelihood.

In case of default at date 1, a firm operating under a high-ability manager yields cash flow of $H$ while a low-ability manager yields zero cash flow. If the firm is liquidated to outsiders and ceases to exist, it will fetch cash flow of $L$. We assume that $2 L<F<H$. The following are the possible outcomes upon default, which occurs if the realization from the investment is zero.

(1) With probability $r(r>0)$, the firm is liquidated to outsiders by creditors, which yields $L$. This may occur due to failure amongst the different creditors of the firm to agree on a reorganization outcome (we discuss below possible explanations for such a failure).

(2) With probability $q(q>0)$, creditors investigate the type of management and find it out. Then, if the manager's ability is found to be low, the manager is fired and the firm is liquidated, realizing cashflow of $L$. If the manager's ability is found to be high, the firm continues with the current manager and realizes cash flow $H$. The likelihood of each such event occurring is 0.5 .

(3) With the remaining probability of $(1-q-r)$ (assumed positive), creditors are unable to learn managerial type and proceed with the current manager. This will yield $H$ or 0 with probability of 0.5 . If the high outcome $H$ is sufficiently high compared to proceeds from liquidation (we assumed that $0.5 H>L$ ), creditors are better off if the firm continues compared to liquidation even if the manager type in unknown.

Assumption (2) is consistent with empirical evidence. For example, Eckbo and Thornton (2003) find that in Sweden, where creditor rights include the automatic firing of 
the manager in default, some firms rehire the dismissed manager with the rehiring probability increasing in managerial quality. ${ }^{3}$

If manager is found to be of low quality and is fired (probability of $0.5 q$ ) or the firm fails to reorganize and is liquidated (probability of $r$ ), managers are assumed to suffer a private cost of $m>0$ due to loss of reputation or private benefits of control. This assumption is consistent with empirical evidence. Gilson (1989), Baird and Rasmussen (2006) and Ozelge (2007) find that upon distress, there is a significantly higher probability of top-management dismissal, especially due to direct intervention by lending banks, compared to firms not in distress. Gilson also documents that managers dismissed in distress suffer a significant private cost in the form of future employment opportunities. Eckbo and Thornton (2003) find that in Sweden, managers of bankrupt companies suffer a median (abnormal) income loss of $47 \%$.

The assumed inefficiency in reorganization, which leads to liquidation rather than continuation, reflects creditors' failure to reach an agreement amongst themselves regarding bankruptcy proceedings. For example, suppose that firm's debt of face value $F$ consists of secured debt of amount $F_{1}$ and unsecured debt of amount $\left(F-F_{1}\right)$, where $F_{l}<$ $L$. Suppose also that secured creditors have claim to all assets of the firm and there is no automatic stay on secured creditors' rights. Then, since secured creditors are fully covered under liquidation but face some default risk in case firm is continued (and managerial type turns out to be low), they have incentives to liquidate the firm. In contrast, unsecured creditors value the continuation outcome. Thus, there is a conflict of interest amongst creditors whether to expend any time and effort in learning about managerial type at all: secured creditors may just prefer to seize and liquidate the assets. Such reorganization failure is also more likely if reorganization petition requires majority consent of creditors and secured (or more generally, senior) creditors can block continuation in favor of liquidation. Another possibility (outside of our model) is that firm's continuation requires additional financing, but due to debt overhang problem, this can be raised only if the firm can arrange supra-priority financing, such as the debtor-inpossession financing in the United States. However, if creditor rights do not allow

\footnotetext{
${ }^{3}$ Managerial quality is increasing in the firm industry-adjusted pre-bankruptcy operating performance and the recovery rate of its debt, and decreasing in the trustee's evaluation of the manager and in the delay from insolvency to filing.
} 
secured creditors' claims to be subordinated in this way, then no continuation may be feasible, resulting in liquidation of the firm.

We assume the probabilities $q$ and $r$ to be a property of the legal environment in which the firm operates, namely of the country's creditor rights. These parameters map directly into their empirical counterparts of creditor right scores (as measured, for example, in LaPorta, Lopez-de-Silanes, Shleifer, and Vishny (1998)). The empirical counterpart for $q$ is the score $M A N A G E S$, which equals 1 if management is not retained in bankruptcy. The counterpart for $r$ is the set of other creditor right scores, namely AUTOSTAY, SECURED and REORG. These correspond to there being no automatic stay on secured creditors' rights, secured creditors being paid first, and reorganization requiring creditors' consent, which as explained above could lead to failure to reorganize due to disagreement amongst creditors. In our model, while MANAGES leads to more information about managerial type and therefore better continuation and liquidation decisions, the other three creditor rights result in inefficient liquidations of the firm. However, all these creditor rights impose a private cost on management and induce in them aversion to risk. We derive this result next.

In the presence of leverage and risk of default, the owner/manager chooses the risk $y$ to maximize the expected value of equity net of the private costs from distress, given as:

$$
p(y)[y-F]+[1-p(y)][-(r+0.5 q) m+(0.5 q+0.5(1-q-r))(H-F)] .
$$

This expression reflects the fact that management suffers a private cost $m$ when the firm is liquidated - either due to failure to reorganize or due to revelation of his type being low - and has residual value in distress in other cases provided there is excess cash flow after creditors are paid off. This latter scenario has a probability of $(0.5 q+0.5(1-q-r))$ since there is excess cash flow after paying creditors only if managerial type is discovered by creditors to be high and firm is continued (probability of $0.5 q$ ) or if managerial type is not discovered but it turns out ex post to be high.

The optimal choice of risk for the levered firm $y^{*}$ is thus given by the first-order condition:

$$
p(y)+p^{\prime}(y)[y-F+(r+0.5 q) m-0.5(1-r)(H-F)]=0,
$$

and, the second-order derivative is 


$$
2 p^{\prime}(y)+p^{\prime \prime}(y)[y-F+(r+0.5 q) m-0.5(1-r)(H-F)] .
$$

Note that since $p^{\prime}(y)<0$ at the optimal risk choice $y^{*}$, we must have

$$
[y-F+(r+0.5 q) m-0.5(1-r)(H-F)]>0,
$$

so that the second-order derivative above is negative and the first-order condition indeed gives the optimum that maximizes the objective of manager. ${ }^{4}$

The three terms after $y$ inside [.] in the condition (4) for $y^{*}$ illustrate the additional effects on risk-taking for a levered firm. The first term, $-F$, reflects the fact that a levered firm has incentives to shift risk given equity's "option" like payoff at date 1. This effect is however not sensitive to creditor right parameters $q$ and $r$. The second term $(r+0.5$ q) $m$ reflects the risk-aversion induced in managerial objective by the fact that management suffers a private cost upon being fired. This effect is increasing in $r$, the failure of creditors to agree on reorganization, and also increasing in $q$, the likelihood that management is fired in bankruptcy, both assumed to be a property of the creditor rights of the country. The third term $-0.5(1-r)(H-F)$ also corresponds to a risk-shifting incentive. This is the "option" effect from date 2 when the firm is continued. Crucially, the magnitude of this effect diminishes in $r$, the likelihood that creditors fail to allow the firm to be efficiently reorganized in bankruptcy.

To summarize, creditor rights that replace management in distress and that are less likely to lead to a reorganization outcome discourage ex-ante risk-taking by firm's management. We can prove these two results formally as follows. Denoting the firstorder condition for management's optimization as $f\left(y^{*}(q, r), q, r\right)=0$, the second-order condition implies $\delta f / \delta q<0$. In turn, taking the derivative of $f$ with respect to $q$ or $r$, and applying the implicit-function theorem gives

$$
\begin{aligned}
& \text { (i) } \operatorname{sign}\left(d y^{*} / d q\right)=\operatorname{sign}(\delta f / \delta q) \text {, which is negative since } \\
& \delta f / \delta q=p^{\prime}(y) m<0,
\end{aligned}
$$

and, similarly,

\footnotetext{
${ }^{4}$ To see this, note that since $p(y)>0$ and $p^{\prime}(y)<0$, the expression $p(y)+p^{\prime}(y)[y-x]$ is greater than zero for all $y<=x$. Hence, the solution to the equation $p(y)+p^{\prime}(y)[y-x]=0$ must satisfy $y>x$.
} 
(ii) $\operatorname{sign}\left(d y^{*} / d r\right)=\operatorname{sign}(\delta f / \delta r)$, which is also negative since

$\delta f / \delta r=p^{\prime}(y)[m+0.5(H-F)]<0$.

Thus, the risk undertaken by a levered firm declines in the likelihood that management is fired in distress and that reorganizations promoting continuations of the firm do not materialize. These two implications constitute the center stage of our empirical investigation.

\section{Data and Empirical Design}

In studying the effects of creditor rights on corporate propensity to take risk, we conduct a number of tests. First, we examine whether the propensity of firms to diversify through mergers and acquisitions and test if this propensity increases as a function of the country's creditor rights, both in the cross-section of countries and in time-series, around changes in creditor rights of a country. Here, we directly observe the action that companies take in order to affect their risk. Since most companies can reduce their risk by applying other means that may be difficult to observe directly, we also conduct a second test of whether companies' operating risk is decreasing in creditor rights. Both of

these tests are conducted in two ways. In one, the unit of observation is a transaction, and in the other, we look at country averages.

The results of these tests are overall consistent with our model. In countries with strong creditor rights, there is greater propensity of companies to do diversifying acquisitions. In general, operating risk is lower in countries with strong creditor rights. Below, we describe our data, tests and results in greater detail. Details of how our various variables are constructed are provided in Table 1.

INSERT TABLE 1 HERE. 


\subsection{Creditor Rights}

The data on creditor rights is taken from LaPorta, Lopez-de-Silanes, Shleifer, and Vishny (1998), whose sample contains data for 49 countries, and records creditor rights provisions in the cross-country sample as of 1994. The variable CRIGHTS is the sum of four provisions: AUTOSTAY, the absence of automatic stay on the assets of the debtor in reorganization; REORG, the requirement of creditors' consent or minimum dividend for a debtor to file for reorganization; SECURED, ranking secured creditors first in the disposition of assets of the bankrupt firm upon filing for reorganization; and MANAGES, the removal of management from managing the activities of the firm upon filing for reorganization. Each of these provisions takes a value of 1, if it is present in the country's bankruptcy code or zero if it is absent. Consequently, the range of values for CRIGHTS is 0 through 4 . We also use the extended sample and detailed creditor rights data of Djankov et al. (2007a) to examine the impact of changes in creditor rights on the subsequent corporate risk-taking.

\subsection{Creditor rights and diversification in M\&A activity}

Our first set of tests is based on measuring corporate risk reduction through diversification, using the mergers and acquisitions activity in countries. The data on acquisitions is obtained from the Securities Data Corporation (SDC)'s Platinum Mergers \& Acquisitions database for the period 1994-2004. We consider only mergers where both the acquirer and the target are in the same country, thus being under the same jurisdiction as it applies to creditor rights. We exclude acquisitions where acquirer comes from the financial industry (SIC header 6) or a regulated industry (SIC headers 48 and 49) since for such acquirers, the motives for diversification may be linked to regulatory requirements to reduce risk and therefore may differ from those presented in our model. We further exclude transactions where the acquirer and the target are the same company (repurchases recorded as acquisitions), transactions where the acquirer is a mutual company, investment company, subsidiary, or state-owned enterprise, and transactions in 
which the percentage acquired from the target is less than 20 percent. $^{5}$ Finally, we include only countries with more than 50 transactions that satisfy the above criteria in our sample period. Additional data requirements related to the control variables, in particular the value of creditor rights as of 1994, reduce our sample to 38 countries, for which we present descriptive statistics in Table 2.

\section{INSERT TABLE 2 HERE.}

We first test the following hypothesis:

Hypothesis I: The propensity to do diversifying acquisitions increases in the strength of the country's creditor rights.

This hypothesis is tested first by estimating the likelihood of same-industry acquisition in a country as a function of the creditor rights in that country, and a set of control variables. An acquisition of a firm that is not in the same industry (defined by the 2-digit SIC code) is considered diversifying. ${ }^{6}$ Comment and Jarrell (1995) show that focused firms (firms whose revenue is concentrated in a fewer segments) have significantly higher idiosyncratic risk. Hence, diversifying acquisitions reduce risk by reducing revenue concentration. By our hypothesis, the likelihood of same-industry mergers and acquisitions in a country should be a decreasing function of the strength of creditor rights. This is studied both at the level of individual acquisitions and at the aggregate country level. For individual transactions, we examine the likelihood of a target firm being in the same industry as the acquirer (Table 3). For the aggregate country level, we analyze the proportion of the same-industry domestic mergers from all domestic mergers in the sample period (Tables 4 and 5).

The explanatory variables that we employ in our analysis are as follows. First and foremost is the measure of creditor rights, the CRIGHTS score from La Porta et al.

\footnotetext{
${ }^{5}$ Our results are robust to a less conservative selection approach, e.g. if we consider all transactions with at least $10 \%$ acquired. Our results are also unchanged when we examine a more conservative sample, e.g. consider only transactions in which the acquirer obtains at least $51 \%$ of the company, the transaction value is at least 1 million US\$, the transaction represents at least $1 \%$ of the total assets of the acquirer, and the transaction is completed within three years of the announcement of the deal. These latter selection criteria are similar to those in Moeller, Schlingemann, and Stulz (2004).

${ }^{6}$ The results are qualitatively similar when we employ industry classification at the 3-digit SIC level.
} 
(1998), and its components, AUTOSTAY, REORG, SECURED and MANAGES. The prediction is that the likelihood of same-industry mergers is lower in countries with stronger creditor rights.

As control variables, we include shareholder rights index, SHRIGHTS, which may positively affect the likelihood of same-industry mergers if they benefit shareholders (Rossi and Volpin, 2004). We include Rule of Law as a proxy for the character of legal rules and the quality of law enforcement, which could influence the development of financial markets (La Porta et al., 1997), and through that channel influence economic growth and the nature of mergers. ${ }^{7}$ We also control for Legal Origin, as creditor- and shareholder rights are both influenced by the legal origins (La Porta et al., 1998). These three legal control variables are obtained from Levine and Demirguc-Kunt (2001) and LaPorta et al. (1998). Their use is also supported by the finding of Classens and Klapper (2005) that they interact with the likelihood of bankruptcies in a country and with creditor rights.

As additional controls, we employ macroeconomic volatility, as it may impact the risk-taking of corporate insiders. We include a direct measure of the country's macroeconomic risk, MacroRisk, the standard deviation of quarterly changes in the country's index of industrial production. ${ }^{8}$ It will have negative coefficient if managers in riskier countries do more diversifying mergers. We also include the logarithm of the country's average real GDP per-capita over 1994-2000 from the Penn World Table Version 6.1 as a proxy for the degree of economic development. The latter control is necessary as developed and developing countries may have different investment opportunity sets (Acemoglu and Zilibotti, 1997). Furthermore, this variable is used in other studies of cross-country comparisons and is perceived to reflect hard-to-quantify country-level characteristics. In the individual merger regression (Table 3), we also control for transaction size and leverage. We include the Transaction Value (the logarithm of the amount paid in US dollars), which shows significant heterogeneity across firms in our sample. And, since leverage may affect the firm's investment policy,

\footnotetext{
${ }^{7}$ LaPorta et al. (1997) point out that stock market capitalization or the total assets of financial institutions are endogenous to economic development, shareholder rights, creditor rights, rule of law, and legal origins. Therefore, we do not control for these variables. Instead of including these (outcome) proxies for equity and debt market development, we include only the (primitive) institutional variables as controls.

${ }^{8}$ See Table 1 for details.
} 
we add two leverage control variables: The acquirer's leverage and the target's leverage. To get around the endogeneity of leverage, both at the firm level and at the country level (since leverage in a country is affected by its creditor's rights, as well as by other country characteristics), we assign as leverage of each firm - both bidder and target - the rank of the industry's leverage in the U.S., which has a low level of creditor rights (CRIGHTS= 1). For that end, we calculate the median leverage, defined as [(total liabilities - deferred taxes) / total assets] of firms in each U.S. 2-digit SIC code industry over the years 19922005 , we then rank the industries by their median leverage and divide them into quartiles. The leverage assigned to an acquirer firm in any country is then the number of the leverage quartile to which its industry belongs. Leverage quartile numbers go from 1 to 4 , 4 being the highest leverage quartile. Finally, to address concerns of covariance across residuals of same-country cases, we follow Bertrand, Duflo and Mullainathan (2004) in clustering the standard errors at the country level (in the OLS regressions). The estimated model is

$\operatorname{Pr}($ same industry merger $)=\alpha^{*}$ CRIGHTS + control variables.

The dependent variable equals 1 if the merger or acquisition is in the same 2-digit industry. Our hypothesis implies that $\alpha<0$.

\section{INSERT TABLE 3 HERE.}

The results, presented in Table 3, strongly support our hypothesis. The coefficient of CRIGHTS is negative and statistically significant (column 1), meaning that stronger creditor rights are associated with lower probability of same-industry merger in the country. The creditor rights components that affect this result most significantly (columns 2 through 5) are AUTOSTAY and MANAGES. The latter, representing the requirement that management does not retain administration of the firm pending the resolution of the reorganization, is the most important determinant (both statistically and economically) of the decision to acquire a same-industry firm, with its effect being more than thrice as strong as the overall effect of CRIGHTS. The results remain the same when we exclude 
the United States from the sample which has by far the largest number of mergers (column 6).

The negative effect of CRIGHTS on same-industry acquisitions is also obtained when we test our hypothesis by a random effects probit model (Guilkey and Murphy, 1993). The results are presented in columns (7) and (8) of Table 3. The coefficient on creditor rights is highly statistically significant, regardless of whether we include all 38 countries or only 37 , excluding the U.S.

Regarding the other variables, SHRIGHTS has positive - although not significant - coefficient. MacroRisk has negative coefficient, meaning that in countries with greater macroeconomic risk, there is greater tendency of firms to do diversifying mergers. Target firm leverage has a significant negative effect on the propensity to do sameindustry mergers, while acquirer's leverage has a positive effect that is insignificant when excluding the U.S.

As robustness check, we re-estimated the model in Table 3 with a variable that captures the strength of antitrust law in a country, following Hylton and Deng (2006). They provide a score of the antitrust law as it pertains to mergers for 2004. While this date is at the end of our sample period, we use it (for lack of another index) assuming that the law has hardly changed over the years. Hylton and Deng's list includes 35 countries that overlap with ours, to which we add data on Hong Kong and Singapore. ${ }^{10}$ We find that this variable, when included in the regression, has insignificant effect. Still, there is a negative and significant effects of CRIGHTS and its components, AUTOSTAY and $M A N A G E S$, as before.

We also examine the effect of cultural differences, following Stulz and Williamson (2003). In particular, we control for the religious composition of the population. Our results on the effect of creditor rights and its components are unchanged.

Finally, we examine the effect of the means of financing of the acquisitions by adding a dummy variable that equals 1 for cash only transactions. Naturally, this variable is endogenous. Still, its effect is insignificant in the regression of all countries, while in the regression that excludes the U.S., its coefficient is positive and significant: 0.035 with

\footnotetext{
${ }^{10}$ For Singapore, it is for 2006.
} 
$t=2.42$. Still, the coefficient of CRIGHTS remains negative and significant. In the regression that excludes the U.S., the coefficient is $-0.013(t=2.54)$.

Next, we test our hypothesis at the aggregate country level, where each country is one observation. Here, large and small countries are treated alike. We calculate for each country the measure $P R O P$, the proportion of same-industry domestic mergers from all domestic mergers in the sample period. Since PROP is a ratio bounded between 0 and 1 , we employ the Theil transformation of the share of same industry mergers:

$P R O P=\ln [S A M E /(1-S A M E)]$,

where $S A M E$ is the proportion of acquisitions in the same two-digit SIC code industry.

\section{INSTER TABLE 4 HERE}

Table 4 presents the results for the model ( $c$ denoting a country):

PROP $_{c}=\beta_{0}+\beta_{1} *$ CRIGHTS + controls.

Our hypothesis that $\beta_{1}<0$ is again supported by the data. The coefficient of CRIGHTS is negative and significant (column 1). When looking at the components (columns 2 through 5), we observe again that AUTOSTAY and MANAGES have negative coefficients, although only MANAGES is highly statistically significant, and its effect is four times as large as the overall effect of CRIGHTS. The coefficient of SECURED is also negative and marginally significant. If secured creditors are always paid first, then violations of absolute priority rule are smaller and management and shareholders anticipate receiving less in a reorganization of the firm, which in turn induces them to take less risk. The negative effect of CRIGHTS on same-industry mergers is similar in column (6), when using the weighted average CRIGHTS over the sample period. The weights are the number of transaction in the years following the year of change in one of the CRIGHTS components, since a change in the law is reflected in transactions in 
subsequent years. The calculation of this variable employs the time series data of the CRIGHTS components in Djankov et al. (2007a). Again, as robustness check we include in the model the merger index from Hylton and Deng (2006). Its coefficient is insignificant, while the coefficient of CRIGHTS remains negative and significant.

Figure 2 plots the variable $P R O P$ for different countries as a function of their CRIGHTS and also shows the best fit implied by column (1) of Table 4, illustrating well the negative relationship between strength of creditor rights and the extent of sameindustry mergers.

\section{INSERT FIGURE 2 HERE.}

To check the robustness of the main results to sample period selection, we again estimate the relationship between PROP and CRIGHTS across countries, splitting the sample period into two, 1994-1999 and 2000-2004, and calculating PROP for each subperiod. In this regression, we allow for unbalanced panel, excluding one sub-period for a given country if it does not have at least 30 transactions in that sub-period. The results, presented in Table 5, again support our hypothesis: creditor rights (especially, no automatic stay on the assets and no stay for management in distress) have a significant negative effect on the proportion of same-industry mergers.

\section{INSERT TABLE 5 HERE.}

\subsection{The effects of changes in creditor rights on diversification in M\&A activity}

Our analysis so far has shown a negative association between a country's creditor rights and the propensity of firms to engage in same-industry acquisitions. Six countries in our sample underwent changes in their creditor rights provisions during our sample period: Indonesia, Israel, Japan, Russia ${ }^{11}$, Sweden, and Thailand. The changes in all these countries implied a decrease by one unit in creditor rights, except for Russia which had a

\footnotetext{
${ }^{11}$ Russia is included only in this table's regressions, not in any other estimation, since it has a unique legal origin. Then, its inclusion with a unique dummy variable for its legal origin will not change any of the results reported.
} 
decrease in 1998 and an increase in 2002. We use these changes in creditor rights to examine whether the propensity of firms to engage in same-industry mergers responded to changes in CRIGHTS. The changes in the bankruptcy code in these countries can be reasonably assumed to be exogenous. They were driven mainly by financial crises (Indonesia, Russia, and Thailand), the need to collect state tax (Russia, 1998) or emulation of the U.S. when switching from more centrally-controlled economy.

Given this backdrop of creditor rights changes in our sample, we estimate the following regression which is a variant of the estimation employed in Table 3:

$\operatorname{Pr}($ same industry merger $)=\alpha^{*} \Delta C R I G H T S_{c}+$ control variables.

The change in CRIGHTS of country c, denoted $\triangle C R I G H T S_{c}$, equals 0 during the period following the weakening of CRIGHTS (the year of the change and the years that follow), and $\triangle C R I G H T S_{c}=1$ during the period that precedes it, when CRIGHTS are stronger. Similarly, $\triangle C R I G H T S_{c}=1$ during the period when CRIGHTS are stonger compared to the previous period of weaker CRIGHTS, during which $\triangle C R I G H T S_{c}=0$. As discussed, all changes in CRIGHTS during the sample period but one made them weaker. For most countries in our sample, $\triangle C R I G H T S=0$ for the entire sample period (i.e., no change). By our hypotheses, we expect that $\alpha<0$. That is, the propensity to engage in same-industry mergers rises if CRIGHTS declines from 1 to 0 .

The control variables are the industry fixed effects, the legal origins (not reported) and the logarithm of acquisition size. We further include year fixed effects and, importantly, country fixed effects in line with the difference-in-differences methodology. We estimate the regression by both linear probability (OLS) and Probit models. We have in this regression 29,567 observations. ${ }^{12}$

\section{INSERT TABLE 6 HERE.}

\footnotetext{
12 Our observation count in the changes regression is lower than in Table 3 because of data requirement: having creditor rights data from Djankov et al. (2007a) on an annual basis for the sample period 1994-2004. This study's data however ends in 2002.
} 
The regression results in Table 6 show that in both OLS and random effects probit analysis, the coefficient on changes in creditor rights is negative and statistically significant, as hypothesized. In particular, the reported coefficient from the random effects probit model corresponds to a marginal effect of -0.240 with $z$-stat of -2.48 . The results thus strongly support our hypothesis that changes in CRIGHTS which weaken them reduce the propensity of firms to diversify through mergers and acquisitions.

\subsection{Creditor rights and firms' operating risk}

We now present a new and independent test of the relationship between creditor rights and corporate risk. So far we have shown that the propensity to engage in diversifying mergers is greater in countries in which creditor rights are strong. However, diversifying acquisitions are not the only means for companies to reduce their risk. Firms can reduce risk by other means which are not directly observed. Therefore, we now measure directly the level of corporate risk and relate it to the creditor rights in the country.

Hypothesis II: The volatility of return on firms' assets is decreasing in the strength of the country's creditor rights.

The risk of corporate operations of firm $j$ in country $c, R I S K_{j, c}$, is computed as the standard deviation of corporate return on assets, using data from Compustat Global Vantage. We first calculate the ratio $E_{j, c, t}=\operatorname{EBITDA}_{j, c, t} / A S S E T S_{j, c, t}$ where $\operatorname{EBITDA}_{j, \mathrm{c}, \mathrm{t}}$ is the sum of operating income after depreciation (data item \#14) and depreciation and amortization expenses (data item \#11), ${ }^{13}$ and $\operatorname{ASSETS}_{i, c, t}$ is the contemporaneous total assets (data item \#89). Data are annual. $E_{j, c, t}$ is calculated for the years 1992-2005, and the entire sample of $E_{j, c, t}$ is winsorized at $0.5 \%$ in both tails of the distribution to account for possible data errors and large outliers. $R I S K_{j, c}$ is calculated as the standard deviation of the $E_{j, c, t}$ series. The entire sample of RISK $_{j, c}$ is again winsorized at $1 \%$ in both tails of

\footnotetext{
${ }^{13}$ We use EBITDA rather than EBIT since countries differ in the way they recognize accounting depreciation, which affect the smoothing of earnings over time.
} 
its distribution to eliminate outliers. We include only firms in the manufacturing industries ${ }^{14}$ with data for at least eight years in 1992-2005.

The estimation model regresses $\operatorname{RISK}_{j, c}$ on $\operatorname{CRIGHTS}_{j, c}$ and a set of control variables:

$\operatorname{RISK}_{j, c}=\gamma^{*}$ CRIGHTS $S_{j, c}+$ control variables.

As in the case of diversifying M\&As, we estimate this model at two levels of aggregation: at the firm level (Table 7) and at the country level (Table 8), using the average risk of the firms in the country. By our hypothesis, the coefficient $\gamma$ of CRIGHTS is negative. The model also includes company's size (logarithm of its initial total assets, as of the beginning its sample data). It is commonly assumed that larger firms are less risky. The model also includes the assigned company's leverage, the rank its industry of quartile (1 to 4 ) of the median industry leverage as measured for industries in the U.S. It is assumed that this leverage represents the inherent leverage rank of the industry and serves as an instrument for the firm's leverage. This is because the firm's own leverage in endogenous.

The estimation of the model of single-firm risk level is done as a panel regression, and the residual standard errors are country-clustered. This regression includes only 35 countries because three countries have insufficient data (we require at least 6 firms in a country), giving us a total of 5,376 firms for the firm-level analysis.

\section{INSERT TABLE 7 HERE.}

The firm-level results in Table 7, columns (1) through (5), support our hypothesis. The coefficient of RISK on CRIGHTS is negative and significant. As in the earlier results on same-industry mergers (Tables 3-5), the most significant components of CRIGHTS that negatively affect RISK are AUTOSTAY and MANAGES. The effect of MANAGES, in particular, remains far larger than the overall effect of CRIGHTS, as in Tables 3-5 and larger than the effect of AUTOSTAY or any other component of CRIGHTS. The results on

\footnotetext{
${ }^{14}$ We exclude utilities and financial firms which are regulated to various extent in different countries.
} 
the effect of CRIGHTS are qualitatively unchanged when the U.S. is excluded from the regression (column (6)). Among the control variables, both assigned firm leverage and firm size have negative and significant effect on the choice of the company risk level.

\section{INSERT TABLE 8 HERE.}

In Table 8, we estimate the RISK-CRIGHTS relationship at the country level, instead of at the firm level as in Table 7. Here, all countries are treated alike, each being a single observation. The dependent variable is RISK ${ }^{*}$, the average of the individual firms' risk measure RISK. The results again support our hypothesis. The coefficient of CRIGHTS is negative and significant at better than 5\%, even though we have only 25 degrees of freedom in this regression. As before, the significant components of CRIGHTS are AUTOSTAY and MANAGES, with the latter being the most effective component of CRIGHTS.

In an un-reported robustness test, we use alternative definitions of RISK, such as logarithm of RISK and the definition of operating risk variability from John, Litov and Yeung (2007). ${ }^{15}$ Our results are qualitatively unchanged.

We have thus established through an independent test that in countries with stronger creditor rights, firms have lower operating risk.

\subsection{Industry-adjusted propensity to reduce risk}

Since countries may differ in the intensities of different industries in them, differences between countries may reflect differences between them in the composition of their industries rather than in their CRIGHTS. Firms in each industry may have intrinsic or technological (industry-specific) propensity to merge within the industry and to choose certain level of risk (for example, due to the industry's production function). To account for this consideration, we employ the method of Rajan and Zingales (1998). We compare the realized propensity of acquirers to choose targets in the same industry,

\footnotetext{
15 In John, Litov, Yeung (2007), the annual firm's return-on-asset ratio is calculated as the deviation of the firm's EBITDA/ASSET from the country's corresponding average ratio for that year. The standard deviation is calculated from these deviations.
} 
and of firms to choose some level of operating risk, with the inherent such characteristic of the industry, and relate the difference between the two to difference in the countries' CRIGHTS.

As proxy for the inherent industry characteristic - the industry propensity to do within-industry mergers and to choose some level of operational risk - we use the respective characteristic in the United States, as do Rajan and Zingales (1998). The United States is appropriate because for the U.S., CRIGHTS is low (it equals 1) and hence, the industry characteristics in it is relatively less likely to manifest corporate or management aversion to risk-taking induced by creditors' rights. In addition, the U.S. has the most developed financial market, the most active takeover market and relatively little constraints on corporate behavior. Consequently, we employ the proportion of sameindustry M\&A acquisitions in the U.S. as a proxy for the technological or inherent propensity of firms in an industry to do same-industry acquisitions, and we use the average of operating risk of the firms in U.S. industries as a proxy of the industry inherent risk.

For the inherent propensity of a firm to do within-industry mergers we calculate $P R O P_{j, U S}(j$ is the acquirer's industry), the ratio of the same industry mergers from total mergers for 2-digit SIC code industries in the U.S. for the period 1994-1997. We compute similarly $P R O P_{j, c}$ for all other countries for the subsequent period, 1998-2004. The criterion for including an industry from a given country is having at least six qualified transactions in that industry during the period 1998-2004, and the calculation of $P_{R O P}, U S$ requires at least six qualified transactions in that industry during 1994-1997. Following the model in Rajan and Zingales (1998), we then estimate the model

$$
\operatorname{PROP}_{j, c}=\beta_{0}+\beta_{1} * \mathrm{PROP}_{j, U S}+\beta_{2} * \text { CRIGHTS }_{c} * \text { PROP }_{j, U S}+\beta_{3} * \text { CRIGHTS }_{c}+\text { controls }
$$

In this regression, an observation is related to industry $j$ in country $c$. The United States is excluded from the sample. The control variables are the legal origins of the country (the estimated values of the key three coefficients are unchanged when these control variables are removed) and industry dummy variables (not reported). We cluster- 
adjust the standard errors at the country level. There are 623 industry-country observations, and the estimation is a panel regression. ${ }^{16}$

We naturally expect $\beta_{1}>0$ and close to unity: the propensity to do same-industry mergers in industry $j$ in any country $c$ is positively related to the propensity of doing that in the U.S. Importantly, we expect $\beta_{2}<0$, since stronger creditor rights in the country mitigates the propensity to do same-industry mergers. We also expect that $\beta_{3}<0$, as before, although our focus is on the sign of $\beta_{2}$.

\section{INSERT TABLE 9 HERE.}

The results in Panel A of Table 9 strongly support our hypothesis. The estimation in column (1) follows the Rajan-Zingales (1998) specification which includes country fixed effects to control for country-specific factors. We obtain that $\beta_{1}$ is significantly positive and insignificantly different from $1,{ }^{17}$ suggesting that the inherent likelihood of acquirers in various countries to do same-industry mergers is similar to the likelihood of doing the same by U.S. acquirers in the same industry. Importantly, this inherent likelihood of doing same-industry mergers is significantly reduced in countries with strong creditor rights: $\beta_{2}$ is negative and highly significant. One standard deviation increase in the interacted term is associated with 7.2\% drop from the mean value of PROP. The same results are obtained in columns (2) and (3), with additional countryspecific variables (but without country fixed effects). The coefficient $\beta_{3}$ of CRIGHTS is negative and significant in a $10 \%$ one-tail test.

Panel B of Table 9 examines the industry operating risk (related to the analysis in Tables 7 and 8), relating it to the industry risk level in the U.S., denoted RISK $_{j, U S}$, and to CRIGHTS. RISK $K_{j, U S}$ is the average of RISK of firms within industry $j$ for each 2-digit SIC code industry in the U.S. during the period 1992-1998. Similarly, $R I S K_{j, c}$ is the average level of RISK of firms in similar industries in other countries, calculated over the

\footnotetext{
${ }^{16}$ We cluster at the country-level by allowing block-diagonal structure in the variance-covariance matrix, where each identity submatrix corresponds to each country in our dataset. Notably, our industry-country panel is unbalanced.

${ }^{17}$ For example, in a test of whether $\left(\beta_{l^{-}}-1\right)$ is different from zero yields a $t$-statistic of 1.07 .
} 
following period 1999-2005. ${ }^{18}$ We then perform the following regression:

$\operatorname{RISK}_{j, c}=\delta_{0}+\delta_{1} * \operatorname{RISK}_{j, U S}+\delta_{2} *{ }$ CRIGHTS $_{c} * \operatorname{RISK}_{j, U S}+\delta_{3} * C R I G H T S_{c}+$ controls.

As in specification (12), an observation represents industry $j$ in country $c$, excluding the U.S. An industry from the U.S. that is included in the analysis needs to have at least three companies with available RISK measures, and a firm should have at least five years of data on $R O A$ to calculate its RISK. Finally, the standard errors are cluster-adjust at the country level. There are 802 industry-country observations, and the estimation is a (unbalanced) panel regression.

Again, we naturally expect $\delta_{1}>0$ and being close to unity, since higher risk in an industry in the U.S. implies that the same industry in another country also has higher risk. Indeed, we obtain that $\delta_{1}$ is significantly positive and insignificantly different from 1 (testing whether $\delta_{1}=1$ yileds a $t$ statistic of 0.72 ). Central to our hypothesis, the estimate coefficient $\delta_{2}$ is negative and significant, as expected. Managers reduce the inherent risk of an industry if creditor rights in that country are stronger. The effect is robust to substituting CRIGHTS in (13) with country fixed effects, as verified in column (1) in Table 9, Panel B.

\subsection{Risk reduction and industry recovery rates}

A final test of the effect of creditor rights on corporate behavior, which is different from those done so far, is the examination of the choice of target in a merger or acquisition by the recovery rate of its assets in default (henceforth recovery). In time of financial distress, a firm with high-recovery assets can liquidate some assets and use the proceeds to avoid default, i.e., to extend the life of the implicit call option that is embedded in the firm's equity. Bidder firms with low-recovery assets are therefore more vulnerable to default risk because they are less able to defer default by asset liquidation. Indeed, Berger, Ofek and Swary (1996) find that a high recovery value of assets (imputed

\footnotetext{
${ }^{18}$ The results are qualitatively unchanged when the variables for both the US and all other countries are calculated over the entire sample period, 1992-2005.
} 
from book value items) have particularly high value for firms in financial distress. Eckbo and Thornton (2003) find that the recovery rate of the firm's debt in default positively affects the likelihood of a manager of a bankrupt company to be rehired after being automatically terminated in Sweden (following its bankruptcy law). That is, increasing the recovery rate of debt in default serves the managerial interest.

We therefore propose the following hypothesis.

Hypothesis III: In economies with strong creditor rights, target firms in high-recovery industries are more likely to be acquired by firms in low-recovery industry.

An acquirer in low-recovery industry, being more vulnerable to default, seeks highrecovery assets that can be more easily liquidated in time of financial distress. The dependent variable in the test of this hypothesis is $\operatorname{Pr}(\mathrm{TH} \cap \mathrm{AL} / \mathrm{TH})$, the probability of acquisition by low-recovery acquirer ( $\mathrm{AL}$ ) of a high-recovery target $(\mathrm{TH})$ within the set of all TH transactions. By our hypothesis, this probability is positively associated with CRIGHTS.

We assign to firms the recovery level of the industry in which they operate, using the data in Acharya, Bharath and Srinivasan (2008, Table 2) which employs historical experience on defaults in the U.S. over the period 1982-1999. Low recovery industries (in terms of 2-SIC code headers) are: transportation (37, 40, 41, 42, 44, 45, 46, 47), high technology and office equipment $(35,36,38)$, consumer/ service sector $(52,53,54,55$, $56,57,58,59,72,73,75,76,78,79)$, and leisure time/ media $(27,48,70)$. High recovery industries are: energy and natural resources $(10,12,13,14,24)$, building products/ homebuilders $(8,15,17,24,28,29,32,34)$, and healthcare/ chemicals ( 28 , 80. $)^{19}$ In the estimation model, the universe is all targets with high recovery, and the bidders are either low-recovery (dependent variable $=1$ ), or high recovery (dependent variable $=0$ ).

\section{INSERT TABLE 10 HERE}

\footnotetext{
${ }^{19}$ We have alternatively followed Dyck and Zingales (2004) and characterize as low recovery rate industries the following ones: mining, manufacturing, and transportation. Our results are similar.
} 
The results in Table 10 support our hypothesis. The coefficient of CRIGHTS is positive and significant for the entire sample, and even more so when the U.S., which by itself constitutes half the sample, is excluded (column (6)). All components of creditor rights have positive coefficients, and with the exclusion of SECURED they are statistically significant. That is, stronger creditor rights induce greater likelihood of a target with high-recovery assets to be acquired by a low-recovery firm. The relatively large coefficient of MANAGES underscores the evidence in Eckbo and Thornton (2003) that in a regime where the manager is laid off in default, the rehiring probability increases in the recovery rate of debt, which in turn is enhanced if the firm owns high-recovery assets.

The model is also estimated as a country-level regression, where the dependent variable is the proportion of all high-recovery targets in the country acquired by lowrecovery bidders (using Theil's transformation). In this regression, each country is considered as a single observation, mitigating the effects of large countries. For sake of parsimony, we do not present the table. In this estimation, the coefficient of CRIGHTS is 0.325 with $t=4.49$, highly significant. ${ }^{20}$

This test provides additional evidence that creditor rights affect the choice of investment - here, an acquisition target - particularly by low-recovery acquirers, which seek to acquire high-recovery targets. As we argue throughout, if investment choices are constrained by creditor rights, they may be suboptimal from an overall economic viewpoint.

\footnotetext{
${ }^{20}$ We further conduct a test in the spirit of this hypothesis, examining the proportion among all low-recovery bidders that seek highrecovery targets. In this regression, the effect of CRIGHTS is insignificant.
} 


\section{Conclusions}

An interesting possibility that emerges from our results is that strong creditor rights may have a "dark" side in terms of their effect on corporate investments and attitude towards risk. Employing several methods, we find that stronger creditor rights in a country induce firms to take less risk and prefer diversifying acquisitions. If these actions would not have otherwise been taken by the firms, it follows that creditor rights have real effect on corporate decisions whose value effects may be questionable.

The existing finance and economics literature generally views strong creditor rights as a positive feature of the law in that they enable firms to raise greater external financing. Our model and empirical work imply that the same creditor rights may destroy firms' incentives to undertake value-enhancing but risky projects, and may induce firms to do value-reducing diversifying acquisitions. Thus, stronger creditor rights are not always optimal. The optimal level of creditor rights may thus have to balance the positive effect on debt capacity of firms and the negative effect on their investment choices. In future work, it would be interesting to get directly at this important tradeoff. 


\section{References}

Acharya, V., S. Bharath, A. Srinivasan, 2008, Understanding the recovery rates on defaulted securities, forthcoming, Journal of Financial Economics.

Acharya, V., R. Sundaram, K. John, 2004, Cross-country variations in capital structures: The role of bankruptcy codes, working paper, New York University.

Acharya, V., K. Subramanian, 2007, Bankruptcy Codes and Innovation. Working Paper, London Business School.

Adler, B. E., 1992, Bankruptcy and risk allocation, Cornell Law Review, Vol. 77, 439489.

Aggarwal, R., A. Samwick, 2003, Why do managers diversify their firms? Agency reconsidered, Journal of Finance, Vol. 58: 71-117.

Allen, F., D. Gale, 2000, Comparing Financial Systems, MIT Press, Cambridge, MA.

Amihud, Y., B. Lev, 1981, Risk reduction as a managerial motive for conglomerate mergers, Bell Journal of Economics, Vol. 12: 605-618.

Baird, D.G., R. K. Rsmussen, 2006, The prime directive. Working Paper, The University of Chicago.

Berger, P., E. Ofek, D. Yermack, 1997, Managerial entrenchment and capital structure decisions, Journal of Finance, Vol. 52: 1411-1438.

Berger, P. G., E. Ofek, I Swary, 1996, Investor valuation of the abandonment option, Journal of Financial Economics, Vol. 42: 257-287.

Bertrand, M., E. Duflo, S. Mullainathan, 2004, How much should we trust differences-indifferences estimates? Quarterly Journal of Economics, Vol. 119: 249-75.

Billett, M. T., T-H. D. King, D. C. Mauer, 2004, Bondholder wealth effects in mergers and acquisitions: New evidence from the 1980s and 1990s, Journal of Finance, Vol. 59: 107-135.

Blum, J., 1999, Do capital adequacy requirements reduce risks in banking? Journal of Banking and Finance, Vol. 23: 755-71.

Blum, J., 2002, Subordinated debt, market discipline, and banks' risk taking, Journal of Banking and Finance, Vol. 26: 1427-1441.

Chava, S., M. Roberts, 2008, How does financing affect investment? The role of debt covenants, Journal of Finance, forthcoming. 
Claessens, S., L. F. Klapper, 2005, Bankruptcy around the world: Explanations of its relative use, American Law and Economic Review, Vol. 7: 253-283.

Comment, R., G.A. Jarrell, 1995, Corporate focus and stock returns. Journal of Financial Economics, Vol 37: 67-87.

Cragg, J.G., S.G. Donald, 1993, Testing identfiability and specification in instrumental variables models, Econometric Theory, Vol. 9: 222-240.

Djankov, S., C. McLeish, A. Shleifer, 2007a, Private credit in 129 countries, Journal of Financial Economics, forthcoming.

Djankov, S., O. Hart, C. McLeish, A. Shleifer, 2007b, Debt enforcement around the world, working paper, Harvard University.

Eckbo, B. E., K. S. Thornburn, 2003, Control benefits and CEO discipline in automatic bankruptcy auctions, Journal of Financial Economics, Vol 69: 227-258.

Gilson, S., 1989, Management turnover and financial distress, Journal of Financial Economics, Vol. 25: 241-262.

Guilkey, D., J. Murphy, 1993, Estimation and testing in the random effects probit model, Journal of Econometrics, 59, 301-317.

Haselmann, R., K. Pistor, V. Vig, 2006, How law affects lending, Working Paper, Columbia Business School.

John, K., L. Litov, B. Yeung, 2007, Corporate Governance and Managerial Risk-taking: theory and evidence, working paper, New York University.

Landier, A., 2006, Entrepreneurship and the Stigma of Failure, Working Paper, Stern School of Business, New York University.

La Porta, R., F. Lopez-de-Silanes, A. Shleifer, R. Vishny, 1997, Legal determinants of external finance," Journal of Finance, Vol. 52: 1131-1150.

La Porta, R., F. Lopez-de-Silanes, A. Shleifer, R. Vishny, 1998, Law and finance, Journal of Political Economy, Vol. 106: 1113-1155.

Levine, R., A. Demirguc-Kunt, 2001, Financial Structure and Economic Growth: A Cross-Country Comparison of Banks, Markets and Development, MIT Press, Cambridge, MA.

Manso, G., 2005, Motivating Innovation, Working Paper, MIT. 
Morck, R., A. Shleifer, R. Vishny, 1990, Do Managerial Objectives Drive Bad Acquisitions? Journal of Finance, 45(1), 31-48.

Moeller, S., F. Schlingemann, R. Stulz, 2004, Firm size and the gains from acquisitions, Journal of Financial Economics, Vol. 73: 201-228

Nini, G., D. Smith, A. Sufi, 2006, Creditor control rights and firm investment policy, working paper, University of Chicago.

Ozelge, S. 2007, The role of banks and private lenders in forced CEO turnover, Working Paper, New York University.

Qiang, J., P. Strahan, 2007. How law \& institutions shape financial contracts: the case of bank loans, Journal of Finance, forthcoming.

Rajan, R., L. Zingales, 1998, Financial dependence and growth, American Economic Review, 88, 559-586.

Rossi, S., P. Volpin, 2004, Cross-country determinants of mergers and acquisitions, Journal of Financial Economics, Vol. 74: 277-304.

Schwartz, A. 2001, Contracting on Bankruptcy, Journal of Law, Economics and Organization, Vol 13: 127-146.

Stulz, R., R. Williamson, 2003, Culture, openness, and finance, Journal of Financial Economics, Vol. 70: 313-349. 
Table 1. Variable Definitions

\begin{tabular}{|c|c|c|}
\hline Main Variables & Definition & Source \\
\hline \multicolumn{3}{|c|}{ Risk-reduction measures } \\
\hline$\overline{P R O P}$ & $\begin{array}{l}\text { Theil transformation of the share of same industry mergers, per country. We define it as follows: } \\
\text { PROP }=\ln [\text { SAME/(1-SAME)]. SAME is the proportion of same 2-digit SIC code industry mergers. }\end{array}$ & $\begin{array}{l}\text { SDC Platinum } \\
\text { Mergers \& } \\
\text { Acquisitions. }\end{array}$ \\
\hline
\end{tabular}

Firm risk $(R I S K)$

$\operatorname{RISK}_{i, c}=\left(\frac{1}{T-1} \sum_{t=1}^{T}\left[E_{i, c, t}-\frac{1}{T} \sum_{t=1}^{T} E_{i, c, t}\right]^{2}\right)^{0.5}$, where $T \geq 8$ and $E_{i, c, t}=\frac{E B I T D A_{i, c, t}}{A_{i, c, t}}$ is the earnings scaled by assets of firm $i$ from country $c$ in year $t$. Data are annual, and the sample period is 1992-2005. The entire data of $E_{i, c, t}$ is winsorized at $0.5 \%$ in both tails to account for extreme observations. The entire firm sample of $R I S K_{i, c}$ is then Winsorized at $1 \%$ in both sides of the sample distribution.

Compustat Global Industrial/Commercial Annual Database.

Country risk (RISK $\left.{ }^{*}\right)$

The average of RISK $_{i, c}$, across firms in country c.

Creditor- Rights Variables

Creditor rights (CRIGHTS)

No automatic stay (AUTOSTAY)

Reorganization (REORG)

Secured debt first (SECURED)

No management stay (MANAGES)

Control Variables GDP-per-capita (in U.S. dollars) $(G D P)$

Macroeconomic Risk (MacroRisk)

Rule of Law $(L A W)$

Legal Origins (SHRIGHTS)
An index aggregating creditor rights, following La Porta and others (1998). It is the sum of the four indexes that follow. CRIGHTS then ranges between 0 and 4 .

Equals one if the reorganization procedure does not impose an automatic stay on the assets of the firm upon filing the reorganization petition, secured creditors are able to seize their collateral after the reorganization petition is approved. It equals zero if such restriction does exist in the law.

Equals one if the reorganization procedure imposes restrictions, such as creditors' consent or minimum dividend for a debtor to be able to file for reorganization. It equals zero for countries without such restrictions.

Equals one if secured creditors are ranked first in the distribution of the proceeds that result from the disposition of the assets of a bankrupt firm, as opposed to other creditors such as employees or government. Equals zero if non-secured creditors, such as the government and workers, are given absolute priority. Equals one if an official appointed by the court, or by the creditors, is responsible for the operation of the business during reorganization, that is management does not retain administration of its property pending the resolution of the reorganization. Equivalently, this variable equals one if the debtor does not keep the administration of its property pending the resolution of the reorganization process, and zero otherwise.

\section{Natural logarithm of the average real GDP per capita in US\$, 1994-2000.}

The standard deviation of the quarterly growth in real industrial production for each country in the period 1990-2004. For some countries, we use instead the index of manufacturing production: Argentina, Chile, Greece, Hong Kong, Indonesia, New Zealand, Peru, Philippines, Singapore and South Africa. For Argentina, Canada, Taiwan and Thailand, data are from the international database of Global Insight. The variable is measure in decimal points.

The assessment of the law and order tradition of the country. Calculated as "average of the months of April and October of the monthly index between 1982 and 1995. Scale from zero to 10, with lower scores for less tradition for law and order."

A dummy variable that identifies the legal origin of the Company law or Commercial Code of each country. The detailed origins are French, German, Nordic (default is Common)

An index that aggregates shareholder rights. "The index is formed by adding one when: (1) the country allows shareholders to mail their proxy vote to the firm, (2) shareholders are not required to deposit their shares prior to the general shareholders' meeting, (3) cumulative voting or proportional representation of minorities in the board of directors is allowed, (4) an oppressed minorities mechanism is in place, (5) the minimum percentage of share capital that entitles a shareholder to call for an extraordinary shareholders' meeting is less than or equal to 10 percent (the sample median), or (6) shareholders have preemptive rights that can be waived only by a shareholders' vote. The index ranges from zero to six."
La Porta et al. (1998), Djankov, McLeish, and Shleifer (2007a)

La Porta et al. (1998)

La Porta et al. (1998)

La Porta et al. (1998)

La Porta et al. (1998)

Penn World Tables, Version 6.1

International

Financial Statistics of

IMF.

International Country

Risk Guide; La Porta et al. (1998).

La Porta et al. (1998) and the CIA Factbook 2003.

Quotation is from La

Porta et al. (1998). 
Table 2. Overall descriptive statistics

Table 2 describes the total number of domestic mergers in the sample countries for 1994-2004. The sample presented consists of the countries for which we have La Porta et al. (1998) data on creditor rights. We exclude countries that have less than 50 qualified transactions in the sample period. A transaction is qualified if the percentage of acquired shares is at least $20 \%$. We exclude financial industry (SIC header 6 ) and regulated industry companies (SIC headers 48 and 49) from the country transaction count. The mergers and acquisition data is from SDC Platinum Mergers and Acquisitions database. The year of creditor rights change is the one from the Djankov et al. (2007a) study. We also present data on the average country operating risk proxy, $R I S K^{*}$.

\begin{tabular}{|c|c|c|c|c|c|c|c|c|}
\hline $\begin{array}{l}\text { Acquirer's } \\
\text { Country }\end{array}$ & $\begin{array}{c}\text { Year of creditor } \\
\text { rights change }\end{array}$ & \# Mergers & $\begin{array}{c}\text { \# Same Industry } \\
\text { Mergers }\end{array}$ & $\begin{array}{c}\text { Operating Risk } \\
\text { Proxy }\end{array}$ & $\begin{array}{c}\text { Shareholder } \\
\text { Rights }\end{array}$ & Creditor Rights & $\begin{array}{c}\text { Macroeconomic } \\
\text { Volatility }\end{array}$ & $\begin{array}{c}\text { \$ GDP per } \\
\text { capita }\end{array}$ \\
\hline & $\begin{array}{c}L A W \\
\text { CHANGE }\end{array}$ & COUNT & SAME & RISK & SHRIGHTS & CRIGHTS & MacroRisk & GDP \\
\hline Argentina & - & 150 & $55.33 \%$ & 0.058 & 4 & 1 & 0.07 & $\$ 7,801$ \\
\hline Australia & - & 2,939 & $61.72 \%$ & 0.121 & 4 & 1 & 0.04 & $\$ 20,948$ \\
\hline Austria & - & 217 & $64.52 \%$ & 0.036 & 2 & 3 & 0.09 & $\$ 26,220$ \\
\hline Belgium & - & 325 & $57.54 \%$ & 0.043 & 0 & 2 & 0.08 & $\$ 24,649$ \\
\hline Brazil & - & 343 & $70.26 \%$ & 0.070 & 3 & 1 & 0.03 & $\$ 4,143$ \\
\hline Canada & - & 3,798 & $61.37 \%$ & 0.094 & 5 & 1 & 0.01 & $\$ 20,647$ \\
\hline Chile & - & 76 & $61.84 \%$ & 0.033 & 5 & 2 & 0.04 & $\$ 4,604$ \\
\hline Denmark & - & 402 & $56.47 \%$ & 0.049 & 2 & 3 & 0.07 & $\$ 32,434$ \\
\hline Finland & - & 881 & $54.60 \%$ & 0.054 & 3 & 1 & 0.08 & $\$ 23,856$ \\
\hline France & - & 2,666 & $59.79 \%$ & 0.045 & 3 & 0 & 0.1 & $\$ 24,033$ \\
\hline Germany & - & 3,524 & $55.31 \%$ & 0.057 & 1 & 3 & 0.04 & $\$ 26,443$ \\
\hline Greece & - & 324 & $47.22 \%$ & 0.043 & 2 & 1 & 0.06 & $\$ 11,219$ \\
\hline Hong Kong & - & 343 & $34.11 \%$ & 0.064 & 5 & 4 & 0.13 & $\$ 23,850$ \\
\hline India & - & 470 & $57.87 \%$ & 0.051 & 5 & 4 & 0.07 & $\$ 423$ \\
\hline Indonesia & 1998 & 76 & $60.53 \%$ & . & 2 & 4 & 0.07 & $\$ 868$ \\
\hline Ireland & - & 206 & $63.59 \%$ & . & 4 & 1 & 0.08 & $\$ 21,376$ \\
\hline Israel & 1996 & 110 & $45.45 \%$ & 0.075 & 3 & 4 & 0.02 & $\$ 16,391$ \\
\hline Italy & - & 876 & $53.31 \%$ & 0.038 & 1 & 2 & 0.12 & $\$ 19,814$ \\
\hline Japan & 2000 & 3,301 & $46.80 \%$ & 0.022 & 4 & 2 & 0.03 & $\$ 36,616$ \\
\hline Malaysia & - & 1,207 & $25.27 \%$ & 0.066 & 4 & 4 & 0.05 & $\$ 3,982$ \\
\hline Mexico & - & 147 & $62.59 \%$ & 0.049 & 1 & 0 & 0.03 & $\$ 4,421$ \\
\hline Netherlands & - & 846 & $57.80 \%$ & 0.059 & 2 & 2 & 0.11 & $\$ 24,802$ \\
\hline New Zealand & - & 343 & $57.73 \%$ & 0.073 & 4 & 3 & 0.06 & $\$ 15,528$ \\
\hline Norway & - & 341 & $58.94 \%$ & 0.079 & 4 & 2 & 0.07 & $\$ 33,844$ \\
\hline Peru & - & 51 & $68.63 \%$ & 0.058 & 3 & 0 & 0.07 & $\$ 2,296$ \\
\hline Philippines & - & 75 & $56.00 \%$ & 0.080 & 3 & 0 & 0.18 & $\$ 1,041$ \\
\hline Portugal & - & 147 & $65.31 \%$ & 0.036 & 3 & 1 & 0.06 & $\$ 10,782$ \\
\hline Singapore & - & 407 & $32.19 \%$ & 0.064 & 4 & 4 & 0.06 & $\$ 22,916$ \\
\hline South Africa & - & 612 & $49.84 \%$ & 0.061 & 5 & 3 & 0.02 & $\$ 3,413$ \\
\hline South Korea & - & 314 & $32.48 \%$ & 0.051 & 2 & 3 & 0.06 & $\$ 9,545$ \\
\hline Spain & - & 1,122 & $64.08 \%$ & 0.040 & 4 & 2 & 0.08 & $\$ 14,535$ \\
\hline Sweden & 1996 & 680 & $58.53 \%$ & 0.067 & 3 & 2 & 0.16 & $\$ 26,812$ \\
\hline Switzerland & - & 463 & $57.67 \%$ & 0.046 & 2 & 1 & 0.07 & $\$ 37,908$ \\
\hline Taiwan & - & 98 & $44.90 \%$ & 0.039 & 3 & 2 & 0.06 & $\$ 12,580$ \\
\hline Thailand & 1999 & 157 & $43.95 \%$ & 0.065 & 2 & 3 & 0.05 & $\$ 2,396$ \\
\hline Turkey & - & 52 & $50.00 \%$ & 0.097 & 2 & 2 & 0.07 & $\$ 2,810$ \\
\hline United & - & & & & & & & \\
\hline Kingdom & & 9,446 & $58.61 \%$ & 0.071 & 5 & 4 & 0.05 & $\$ 21,767$ \\
\hline United States & - & 40,656 & $59.07 \%$ & 0.088 & 5 & 1 & 0.01 & $\$ 30,899$ \\
\hline
\end{tabular}


Table 3. Merger-level analysis: proportion of same-industry mergers

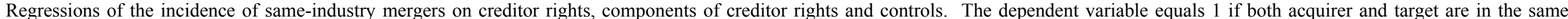

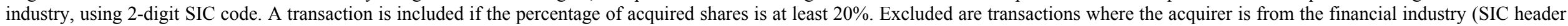

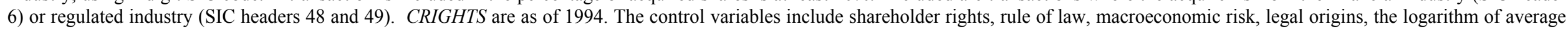

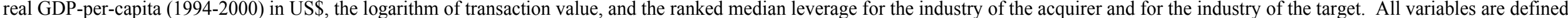

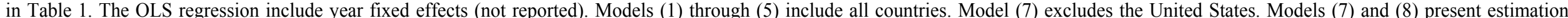

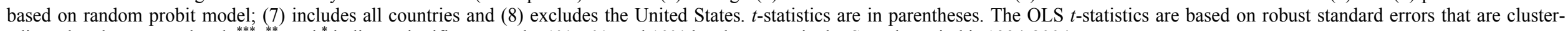
adjusted at the country level. ${ }^{* * *},{ }^{* *}$, and ${ }^{*}$ indicate significance at the $1 \%, 5 \%$, and $10 \%$ levels, respectively. Sample period is $1994-2004$.

\begin{tabular}{|c|c|c|c|c|c|c|c|c|}
\hline & \multicolumn{5}{|c|}{ OLS } & \multirow[b]{2}{*}{ Excluding U.S. } & \multicolumn{2}{|c|}{ Probit } \\
\hline & \multicolumn{5}{|c|}{ All countries } & & All countries & \multirow{2}{*}{$\begin{array}{c}\text { Excluding U.S. } \\
(8)\end{array}$} \\
\hline & $(1)$ & $(2)$ & (3) & (4) & $(5)$ & $(6)$ & $(7)$ & \\
\hline \multirow[t]{2}{*}{ CRIGHTS } & $-0.015^{* *}$ & & & & & $-0.017^{* *}$ & $-0.056^{* * *}$ & $-0.061^{* * *}$ \\
\hline & $(2.21)$ & & & & & $(2.16)$ & (3.8) & $(3.63)$ \\
\hline AUTOSTAY & & $\begin{array}{c}-0.042^{* *} \\
(2.45)\end{array}$ & & & & & & \\
\hline \multirow[t]{2}{*}{$R E O R G$} & & & -0.021 & & & & & \\
\hline & & & $(1.13)$ & & & & & \\
\hline \multirow[t]{2}{*}{ SECURED } & & & & 0.001 & & & & \\
\hline & & & & $(0.02)$ & & & & \\
\hline \multirow[t]{2}{*}{ MANAGES } & & & & & $-0.057^{* * *}$ & & & \\
\hline & & & & & (3.07) & & & \\
\hline \multirow[t]{2}{*}{ SHRIGHTS } & 0.010 & 0.007 & 0.006 & 0.004 & $0.018^{*}$ & 0.012 & 0.027 & 0.030 \\
\hline & $(0.92)$ & $(0.64)$ & $(0.49)$ & $(0.35)$ & $(1.74)$ & $(1.01)$ & $(1.49)$ & $(1.53)$ \\
\hline \multirow[t]{2}{*}{ Rule of Law } & $0.121^{* * *}$ & $0.131^{* * *}$ & $0.114^{* * *}$ & $0.111^{* * *}$ & $0.113^{* * *}$ & $0.094^{* * *}$ & $0.241^{* * *}$ & $0.215^{* * *}$ \\
\hline & $(4.43)$ & $(4.57)$ & $(3.69)$ & $(3.33)$ & $(4.35)$ & $(3.15)$ & $(3.98)$ & $(3.27)$ \\
\hline \multirow[t]{2}{*}{ French Legal Origin } & $0.142^{* * *}$ & $0.155^{* * *}$ & $0.162^{* * *}$ & $0.174^{* * *}$ & $0.139^{* * * *}$ & $0.13^{* * *}$ & $0.331^{* * *}$ & $0.334^{* * *}$ \\
\hline & $(3.56)$ & $(3.84)$ & $(3.71)$ & $(4.55)$ & $(3.47)$ & $(3.81)$ & $(4.51)$ & $(4.18)$ \\
\hline \multirow[t]{2}{*}{ German Legal Origin } & $-0.051^{* *}$ & $-0.06^{* * *}$ & $-0.068^{* * *}$ & $-0.066^{* * *}$ & -0.016 & $-0.073^{* * *}$ & $-0.105^{*}$ & -0.094 \\
\hline & $(2.41)$ & $(2.96)$ & $(3.38)$ & (3.09) & $(0.55)$ & (3.04) & $(1.78)$ & $(1.39)$ \\
\hline \multirow[t]{2}{*}{ Nordic Legal Origin } & 0.030 & 0.025 & 0.057 & 0.066 & 0.016 & 0.031 & 0.082 & 0.087 \\
\hline & $(0.53)$ & $(0.45)$ & $(0.93)$ & (1.09) & $(0.32)$ & $(0.57)$ & $(1.05)$ & $(1.06)$ \\
\hline \multirow[t]{2}{*}{ MacroRisk } & $-1.027^{* * *}$ & $-1.127^{* * *}$ & $-1.345^{* * *}$ & $-1.612^{* * *}$ & $-0.857^{* * *}$ & $-1.062^{* * *}$ & $-2.449^{* * *}$ & $-2.357^{* * *}$ \\
\hline & $(2.72)$ & $(3.31)$ & $(3.38)$ & $(5.25)$ & $(2.78)$ & $(2.77)$ & $(3.75)$ & $(3.41)$ \\
\hline \multirow[t]{2}{*}{ Log GDP per capita } & $-0.069^{* * *}$ & $-0.072^{* * *}$ & $-0.061^{* * *}$ & $-0.055^{* * *}$ & $-0.069^{* * *}$ & $-0.05^{* * *}$ & $-0.155^{* * *}$ & $-0.143^{* * *}$ \\
\hline & $(4.5)$ & $(4.73)$ & $(3.57)$ & $(3.13)$ & $(4.57)$ & $(3.21)$ & $(4.02)$ & $(3.3)$ \\
\hline \multirow[t]{2}{*}{ Log( Transaction Value) } & $0.008^{* * *}$ & $0.009^{* * *}$ & $0.009^{* * *}$ & $0.009^{* * *}$ & $0.008^{* *}$ & 0.005 & $0.022^{* * *}$ & $0.01^{* *}$ \\
\hline & $(2.69)$ & $(2.75)$ & $(2.82)$ & (2.9) & $(2.47)$ & $(1.16)$ & $(6.45)$ & $(2.01)$ \\
\hline \multirow{3}{*}{$\begin{array}{l}\text { Ranked median leverage } \\
\text { for acquirer's industry }\end{array}$} & & & & & & & & \\
\hline & $0.016^{*}$ & $0.016^{*}$ & $0.015^{*}$ & $0.015^{*}$ & $0.016^{*}$ & -0.001 & $0.033^{* * *}$ & -0.006 \\
\hline & $(1.83)$ & $(1.81)$ & $(1.76)$ & $(1.72)$ & $(1.88)$ & $(0.11)$ & (4.4) & $(0.56)$ \\
\hline \multirow{3}{*}{$\begin{array}{l}\text { Ranked median leverage } \\
\text { for target's industry }\end{array}$} & & & & & & & & \\
\hline & $-0.043^{* * *}$ & $-0.043^{* * *}$ & $-0.043^{* * *}$ & $-0.043^{* * *}$ & $-0.043^{* * *}$ & $-0.034^{* * *}$ & $-0.107^{* * *}$ & $-0.086^{* * *}$ \\
\hline & $(5.96)$ & (5.99) & $(6.04)$ & $(6.08)$ & $(5.86)$ & $(3.65)$ & $(14.02)$ & $(8.01)$ \\
\hline
\end{tabular}




\begin{tabular}{|c|c|c|c|c|c|c|c|c|}
\hline Sample period & 1994-2004 & 1994-2004 & 1994-2004 & 1994-2004 & 1994-2004 & 1994-2004 & 1994-2004 & 1994-2004 \\
\hline Year Fixed Effect & Yes & Yes & Yes & Yes & Yes & Yes & No & No \\
\hline Number of countries & 38 & 38 & 38 & 38 & 38 & 37 & 38 & 37 \\
\hline Observations & 33,221 & 33,221 & 33,221 & 33,221 & 33,221 & 15,730 & 33,221 & 15,730 \\
\hline R-squared & $1.9 \%$ & $1.9 \%$ & $1.8 \%$ & $1.8 \%$ & $1.9 \%$ & $2.4 \%$ & - & - \\
\hline Chi-squared & - & - & - & - & - & - & 370.1 & 189.1 \\
\hline
\end{tabular}


Table 4. Country-level analysis: proportion of same-industry mergers

The dependent variable is the fraction of same-industry mergers (2-digit SIC code) out of all mergers in the country, employing Theil's transformation of the fraction. A country is included in our sample if it has at least 50 qualified transactions over the sample period. A qualified transaction is where at least $20 \%$ of the target is acquired. Excluded are acquirers from the financial industry (SIC header 6) and regulated industry companies (SIC headers 48 and 49). The sample period is 1994-2004. All variables are defined in Table 1. Model (6) uses a value-weighted average of the country creditor rights time series (from Djankov et al. (2007a)), where the weights are the number of M\&A transactions within a given country in the subsequent year. $t$-statistics (in parentheses) are based on robust standard errors. ${ }^{* * *},{ }^{* *}$, and ${ }^{*}$ indicate significance at the $1 \%, 5 \%$, and $10 \%$ levels, respectively.

\begin{tabular}{|c|c|c|c|c|c|c|}
\hline & $(1)$ & (2) & (3) & (4) & (5) & (6) \\
\hline CRIGHTS & $\begin{array}{c}-0.141^{* *} \\
(2.43)\end{array}$ & & & & & \\
\hline Average CRIGHTS & & & & & & $\begin{array}{c}-0.127^{* *} \\
(2.16)\end{array}$ \\
\hline AUTOSTAY & & $\begin{array}{l}-0.226 \\
(1.55)\end{array}$ & & & & \\
\hline REORG & & & $\begin{array}{l}-0.087 \\
(0.67)\end{array}$ & & & \\
\hline SECURED & & & & $\begin{array}{c}-0.236^{*} \\
(1.89)\end{array}$ & & \\
\hline MANAGES & & & & & $\begin{array}{c}-0.539^{* * *} \\
(3.37)\end{array}$ & \\
\hline SHRIGHTS & $\begin{array}{l}0.034 \\
(0.91)\end{array}$ & $\begin{array}{l}0.027 \\
(0.57)\end{array}$ & $\begin{array}{l}0.057 \\
(1.51)\end{array}$ & $\begin{array}{l}0.062^{*} \\
(1.84)\end{array}$ & $\begin{array}{l}0.043 \\
(1.35)\end{array}$ & $\begin{array}{l}0.044 \\
(1.21)\end{array}$ \\
\hline Rule of Law & $\begin{array}{l}0.167^{*} \\
(1.91)\end{array}$ & $\begin{array}{l}0.173^{*} \\
(1.89)\end{array}$ & $\begin{array}{l}0.168^{*} \\
(1.83)\end{array}$ & $\begin{array}{c}0.182^{* *} \\
(2.06)\end{array}$ & $\begin{array}{l}0.079 \\
(0.95)\end{array}$ & $\begin{array}{c}0.176^{* *} \\
(2.09)\end{array}$ \\
\hline French Legal Origin & $\begin{array}{l}0.325^{*} \\
(1.92)\end{array}$ & $\begin{array}{l}0.44^{* *} \\
(2.23)\end{array}$ & $\begin{array}{c}0.579^{* * *} \\
(3.02)\end{array}$ & $\begin{array}{c}0.542^{* * *} \\
(3.02)\end{array}$ & $\begin{array}{l}0.226 \\
(1.51)\end{array}$ & $\begin{array}{l}0.406^{* *} \\
(2.22)\end{array}$ \\
\hline German Legal Origin & $\begin{array}{l}0.053 \\
(0.23)\end{array}$ & $\begin{array}{l}0.112 \\
(0.47)\end{array}$ & $\begin{array}{l}0.123 \\
(0.48)\end{array}$ & $\begin{array}{l}0.166 \\
(0.68)\end{array}$ & $\begin{array}{l}-0.034 \\
(0.18)\end{array}$ & $\begin{array}{l}0.071 \\
(0.30)\end{array}$ \\
\hline Nordic Legal Origin & $\begin{array}{l}0.243 \\
(1.38)\end{array}$ & $\begin{array}{l}0.252 \\
(1.28)\end{array}$ & $\begin{array}{l}0.384^{*} \\
(1.77)\end{array}$ & $\begin{array}{l}0.38^{*} \\
(1.83)\end{array}$ & $\begin{array}{l}0.090 \\
(0.59)\end{array}$ & $\begin{array}{l}0.209 \\
(1.05)\end{array}$ \\
\hline MacroRisk & $\begin{array}{l}-1.856 \\
(1.45)\end{array}$ & $\begin{array}{c}-1.871 \\
(1.3)\end{array}$ & $\begin{array}{c}-2.149 \\
(1.3)\end{array}$ & $\begin{array}{l}-2.260 \\
(1.43)\end{array}$ & $\begin{array}{c}-2.272^{* *} \\
(2.13)\end{array}$ & $\begin{array}{l}-1.703 \\
(1.25)\end{array}$ \\
\hline Log GDP per capita & $\begin{array}{r}-0.165 \\
(1.43) \\
\end{array}$ & $\begin{array}{l}-0.155 \\
(1.37) \\
\end{array}$ & $\begin{array}{l}-0.137 \\
(1.23) \\
\end{array}$ & $\begin{array}{r}-0.136 \\
(1.16) \\
\end{array}$ & $\begin{array}{r}-0.116 \\
(1.11) \\
\end{array}$ & $\begin{array}{r}-0.133 \\
(1.25) \\
\end{array}$ \\
\hline Sample period & 1994-2004 & 1994-2004 & 1994-2004 & 1994-2004 & 1994-2004 & 1994-2004 \\
\hline Observations & 38 & 38 & 38 & 38 & 38 & 38 \\
\hline R-squared & $42.9 \%$ & $35.9 \%$ & $32.2 \%$ & $34.7 \%$ & $51.0 \%$ & $38.5 \%$ \\
\hline
\end{tabular}


Table 5. Country-level analysis across two sub-periods: proportion of same-industry mergers

The dependent variable is the proportion of same-industry mergers (2-digit SIC code) out of all mergers in the country, employing Theil's transformation. This table is identical to Table 4, except that the proportion of same-industry mergers is calculated separately for each of the two subperiod, 1994-1999 and 2000-2004. A country in included in the sample if it has at least 30 qualified transactions for each sub-period. The rest is as in Table 4.

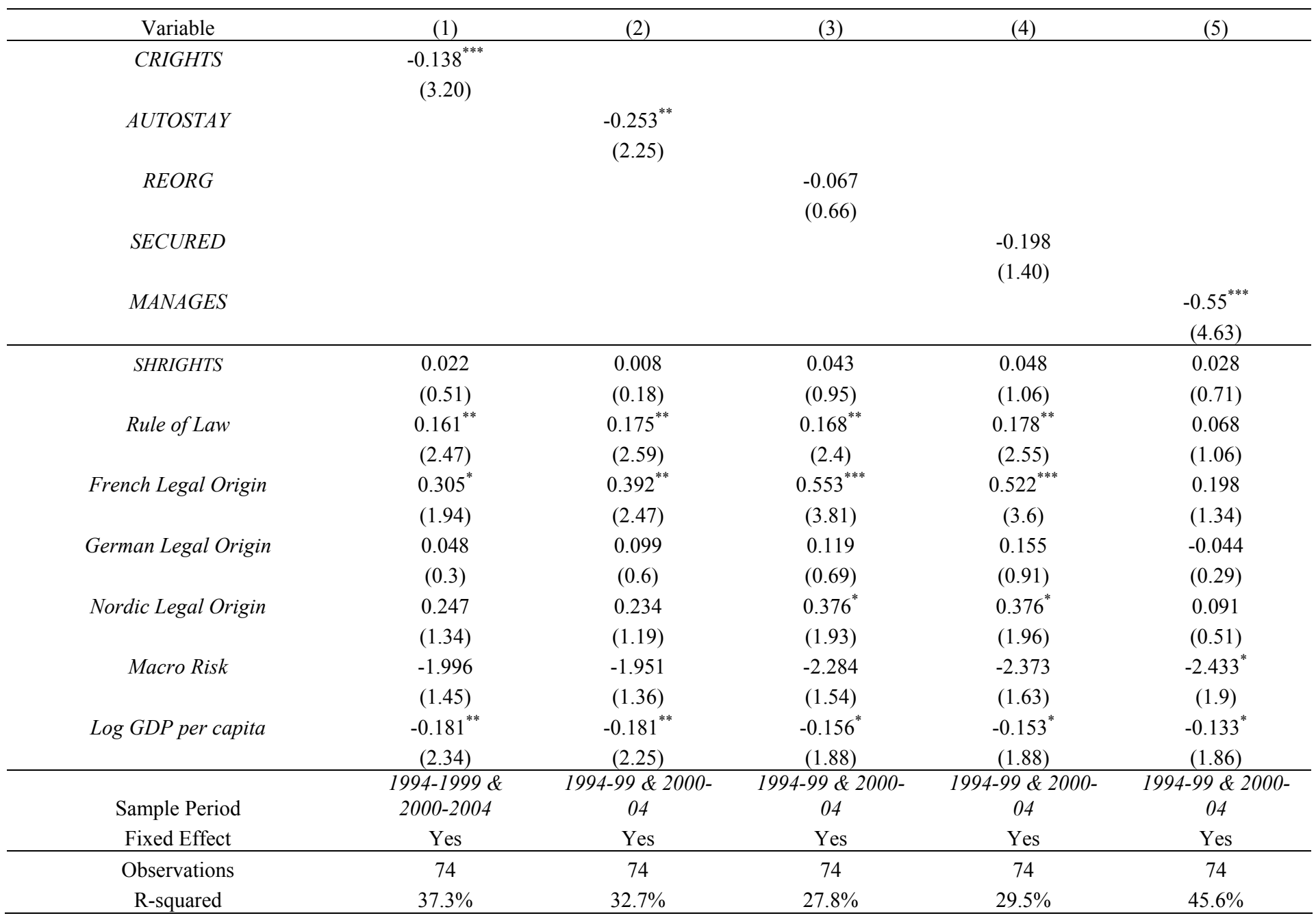


Table 6. Causality Regressions, merger-level analysis of changes in bankruptcy law

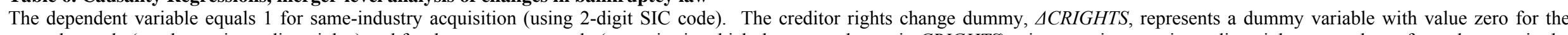

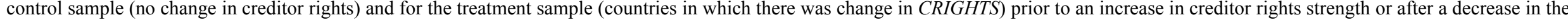

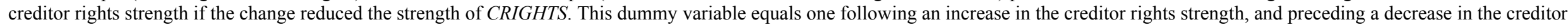

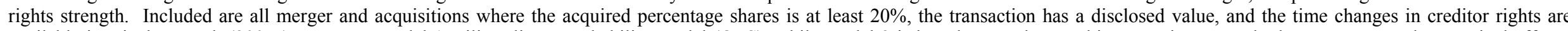

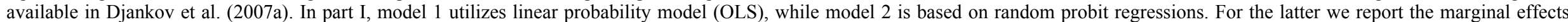

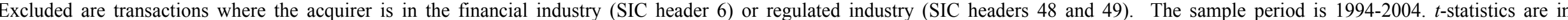

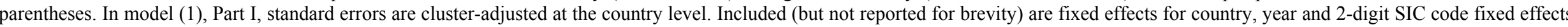

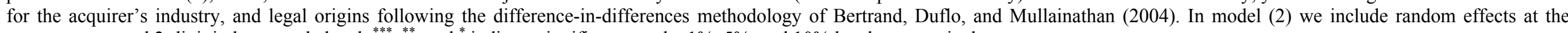
country, year, and 2-digit industry code level. ${ }^{* * *},{ }^{* *}$, and ${ }^{*}$ indicate significance at the $1 \%, 5 \%$, and $10 \%$ levels, respectively.

\begin{tabular}{|c|c|c|}
\hline & \multicolumn{2}{|c|}{ Part I. Mutivariate Analysis } \\
\hline & $(1)$ & $(2)$ \\
\hline & Linear probability models & Probit models \\
\hline & $\operatorname{Pr}(S A M E)$ & $\operatorname{Pr}(S A M E)$ \\
\hline$\Delta C R I G H T S_{\mathrm{c}, \mathrm{t}}$ & $\begin{array}{c}-0.069^{* * *} \\
(3.19)\end{array}$ & $\begin{array}{c}-0.240^{* * *} \\
(2.48)\end{array}$ \\
\hline $\begin{array}{c}\text { Log (Transaction } \\
\text { Value })\end{array}$ & $\begin{array}{l}0.01^{*} \\
(1.88) \\
\end{array}$ & $\begin{array}{c}0.034^{* * *} \\
(8.57)\end{array}$ \\
\hline Fixed Effects & Yes: country, year, and industry & No \\
\hline Random Effects & No & Yes: country, year, and industry \\
\hline \multirow[t]{3}{*}{ Observations } & 29,567 & 29,548 \\
\hline & \multicolumn{2}{|c|}{ Part II. Details of Creditor Rights Changes } \\
\hline & Year of law change & Detail of change \\
\hline Indonesia & 1998 & Change to SECURED $=0$ \\
\hline Israel & 1996 & Introduction of automatic stay, i.e. $A U T O S T A Y=0$ \\
\hline Japan & 2000 & $\begin{array}{l}\text { Change to } S E C U R E D=0 \\
\text { 1998: Change to } M A N A G E S=0\end{array}$ \\
\hline Russia & 1998 and 2002 & 2002: Re-instating $M A N A G E S=1$. \\
\hline Sweden & 1996 & Change to $R E O R G=0$ \\
\hline Thailand & 1999 & Change to $R E O R G=0$. \\
\hline
\end{tabular}




\section{Table 7. Operating risk and creditor rights: RISK at firm level}

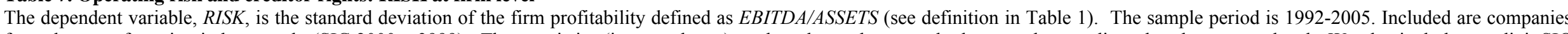

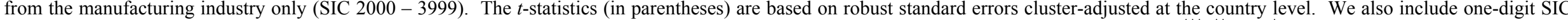

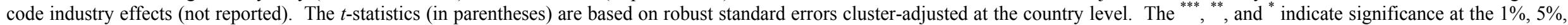
and $10 \%$ levels, respectively.

\begin{tabular}{|c|c|c|c|c|c|c|}
\hline & \multicolumn{5}{|c|}{ All countries } & \multirow{2}{*}{$\begin{array}{c}\text { Exclude U.S. } \\
(6)\end{array}$} \\
\hline & (1) & $(2)$ & (3) & (4) & $(5)$ & \\
\hline \multirow[t]{2}{*}{ CRIGHTS } & $-0.007^{* * *}$ & & & & & $-0.008^{* *}$ \\
\hline & (3.33) & & & & & $(2.62)$ \\
\hline \multirow[t]{2}{*}{ AUTOSTAY } & & $-0.016^{* *}$ & & & & \\
\hline & & $(2.61)$ & & & & \\
\hline \multirow[t]{2}{*}{$R E O R G$} & & & -0.003 & & & \\
\hline & & & $(0.47)$ & & & \\
\hline \multirow[t]{2}{*}{ SECURED } & & & & -0.010 & & \\
\hline & & & & $(0.97)$ & & \\
\hline \multirow[t]{2}{*}{$M A N A G E S$} & & & & & $-0.028^{* * *}$ & \\
\hline & & & & & $(7.17)$ & \\
\hline \multirow[t]{2}{*}{ SHRIGHTS } & -0.004 & $-0.006^{*}$ & -0.003 & -0.003 & -0.001 & -0.005 \\
\hline & $(1.5)$ & $(1.95)$ & $(1.11)$ & $(1.23)$ & $(0.51)$ & $(1.59)$ \\
\hline \multirow[t]{2}{*}{ Rule of Law } & -0.002 & -0.001 & 0.003 & 0.005 & $-0.011^{* *}$ & -0.002 \\
\hline & $(0.37)$ & $(0.01)$ & $(0.76)$ & $(1.04)$ & $(2.20)$ & $(0.2)$ \\
\hline \multirow[t]{2}{*}{ French Legal Origin } & $-0.031^{* *}$ & $-0.028^{* *}$ & -0.013 & $-0.017^{*}$ & $-0.03^{* * *}$ & $-0.038^{* * *}$ \\
\hline & $(2.33)$ & $(2.31)$ & $(1.05)$ & (1.7) & $(3.31)$ & (2.87) \\
\hline \multirow[t]{2}{*}{ German Legal Origin } & $-0.036^{* * *}$ & $-0.04^{* * *}$ & $-0.033^{* * *}$ & $-0.032^{* * *}$ & $-0.025^{* * *}$ & $-0.044^{* * *}$ \\
\hline & $(3.94)$ & $(3.94)$ & $(3.5)$ & $(3.76)$ & $(4.36)$ & $(4.64)$ \\
\hline \multirow[t]{2}{*}{ Nordic Legal Origin } & -0.019 & $-0.023^{*}$ & -0.011 & -0.012 & $-0.021^{* *}$ & $-0.024 *$ \\
\hline & $(1.58)$ & $(1.88)$ & $(0.89)$ & $(0.98)$ & (1.99) & $(1.94)$ \\
\hline \multirow[t]{2}{*}{ MacroRisk } & -0.038 & -0.069 & -0.122 & -0.142 & -0.027 & 0.015 \\
\hline & $(0.44)$ & $(0.81)$ & $(1.09)$ & $(1.54)$ & $(0.40)$ & $(0.20)$ \\
\hline \multirow[t]{2}{*}{ Log GDP per capita } & -0.035 & -0.059 & -0.118 & -0.131 & -0.026 & -0.026 \\
\hline & $(0.38)$ & $(0.66)$ & $(1.03)$ & $(1.46)$ & $(0.38)$ & $(0.3)$ \\
\hline
\end{tabular}




\begin{tabular}{ccccccc} 
Ranked industry median leverage & $-0.005^{* * *}$ & $-0.005^{* * *}$ & $-0.006^{* * *}$ & $-0.006^{* * *}$ & $-0.005^{* * *}$ & $-0.003^{* * *}$ \\
& $(3.62)$ & $(3.78)$ & $(3.96)$ & $(3.95)$ & $(3.42)$ & $(3.54)$ \\
Log of initial total assets & $-0.013^{* * *}$ & $-0.013^{* * *}$ & $-0.013^{* * *}$ & $-0.013^{* * *}$ & $-0.013^{* * *}$ & $-0.01^{* * *}$ \\
& $(5.25)$ & $(5.33)$ & $(5.27)$ & $(5.25)$ & $(5.13)$ & $(5.51)$ \\
\hline Observations & 5,394 & 5,394 & 5,394 & 5,394 & 5,394 & 3,812 \\
R-squared & $29.3 \%$ & $29.1 \%$ & $28.5 \%$ & $28.6 \%$ & $30.2 \%$ & $23.2 \%$ \\
Number of countries & 35 & 35 & 35 & 35 & 35 & 34 \\
\hline
\end{tabular}




\section{Table 8. Country-level operating risk, RISK ${ }^{*}$, and creditor rights:}

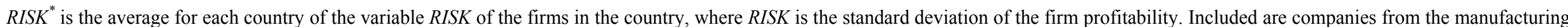

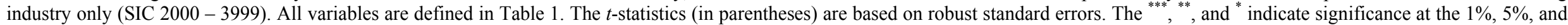
$10 \%$ levels, respectively.

\begin{tabular}{|c|c|c|c|c|c|}
\hline & (1) & $(2)$ & (3) & (4) & $(5)$ \\
\hline CRIGHTS & $\begin{array}{c}-0.008^{* *} \\
(2.47)\end{array}$ & & & & \\
\hline AUTOSTAY & & $\begin{array}{c}-0.018^{* *} \\
(2.32)\end{array}$ & & & \\
\hline REORG & & & $\begin{array}{c}-0.0030 \\
(0.38)\end{array}$ & & \\
\hline SECURED & & & & $\begin{array}{c}-0.0050 \\
(0.58)\end{array}$ & \\
\hline MANAGES & & & & & $\begin{array}{c}-0.031^{* * *} \\
(3.72)\end{array}$ \\
\hline SHRIGHTS & $\begin{array}{c}-0.0020 \\
(0.87)\end{array}$ & $\begin{array}{c}-0.0030 \\
(1.22)\end{array}$ & $\begin{array}{c}-0.0010 \\
(0.37)\end{array}$ & $\begin{array}{c}-0.0010 \\
(0.33)\end{array}$ & $\begin{array}{c}-0.0010 \\
(0.67)\end{array}$ \\
\hline Rule of Law & $\begin{array}{c}-0.0020 \\
(0.6)\end{array}$ & $\begin{array}{c}-0.0010 \\
(0.33)\end{array}$ & $\begin{array}{c}-0.0010 \\
(0.2)\end{array}$ & $\begin{array}{c}0.0000 \\
(0.12)\end{array}$ & $\begin{array}{c}-0.007^{* *} \\
(2.14)\end{array}$ \\
\hline MacroRisk & $\begin{array}{c}0.0460 \\
(0.66)\end{array}$ & $\begin{array}{c}0.0480 \\
(0.56)\end{array}$ & $\begin{array}{c}0.0100 \\
(0.1)\end{array}$ & $\begin{array}{l}0.0050 \\
(0.05)\end{array}$ & $\begin{array}{l}0.0310 \\
(0.44)\end{array}$ \\
\hline Log GDP per capita & $\begin{array}{c}0.0010 \\
(0.2)\end{array}$ & $\begin{array}{c}0.0000 \\
(0.07)\end{array}$ & $\begin{array}{c}0.0000 \\
(0.05)\end{array}$ & $\begin{array}{c}0.0000 \\
(0.09)\end{array}$ & $\begin{array}{c}0.0040 \\
(0.94)\end{array}$ \\
\hline French Legal Origin & $\begin{array}{c}-0.041^{* * *} \\
(3.44)\end{array}$ & $\begin{array}{c}-0.038^{* * *} \\
(3.51)\end{array}$ & $\begin{array}{c}-0.024^{* *} \\
(2.32)\end{array}$ & $\begin{array}{c}-0.024^{* * *} \\
(2.72)\end{array}$ & $\begin{array}{r}-0.048^{* * *} \\
(4.66)\end{array}$ \\
\hline German Legal Origin & $\begin{array}{c}-0.041^{* * *} \\
(3.91)\end{array}$ & $\begin{array}{c}-0.04^{* * *} \\
(3.33)\end{array}$ & $\begin{array}{c}-0.035^{* * *} \\
(3.07)\end{array}$ & $\begin{array}{c}-0.034^{* * *} \\
(3.23)\end{array}$ & $\begin{array}{c}-0.045^{* * *} \\
(4.92)\end{array}$ \\
\hline Nordic Legal Origin & $\begin{array}{c}-0.023^{*} \\
(1.86)\end{array}$ & $\begin{array}{c}-0.025^{* *} \\
(1.97)\end{array}$ & $\begin{array}{c}-0.0130 \\
(1.11)\end{array}$ & $\begin{array}{c}-0.0130 \\
(1.12)\end{array}$ & $\begin{array}{c}-0.033^{* * *} \\
(2.64)\end{array}$ \\
\hline Observations & 35 & 35 & 35 & 35 & 35 \\
\hline R-squared & $47.0 \%$ & $45.1 \%$ & $34.0 \%$ & $34.3 \%$ & $56.2 \%$ \\
\hline
\end{tabular}




\section{Table 9. Industry-level regressions (Rajan-Zingales (1998) methodology)}

\section{Panel A: Industry level of same-industry mergers}

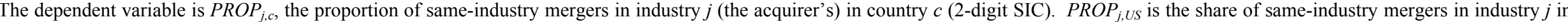

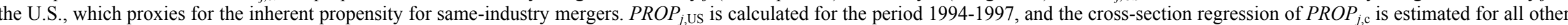

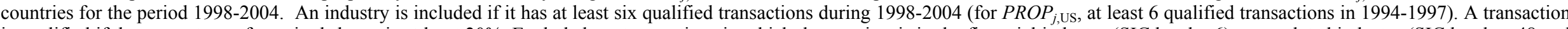

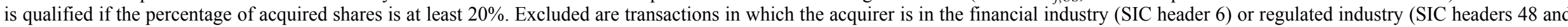

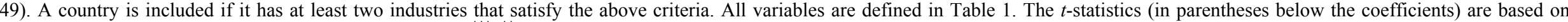
robust standard errors cluster-adjusted at the country level. ${ }^{* * *},{ }^{* *}$, and * indicate significance at the $1 \%, 5 \%$, and $10 \%$ levels, respectively.

\begin{tabular}{|c|c|c|c|}
\hline & (1) & $(2)$ & $(3)$ \\
\hline \multirow[t]{2}{*}{$P R O P_{j, U S}$} & $1.158^{* * *}$ & $1.175^{* * *}$ & $1.173^{* * *}$ \\
\hline & $(7.82)$ & $(7.75)$ & $(7.72)$ \\
\hline \multirow[t]{2}{*}{$C_{R I G H T S} * P_{R O P} P_{j, U S}$} & $-0.199^{* * *}$ & $-0.21^{* * *}$ & $-0.209^{* * *}$ \\
\hline & $(4.56)$ & $(4.45)$ & $(4.43)$ \\
\hline \multirow[t]{2}{*}{ CRIGHTS } & & -0.280 & -0.267 \\
\hline & & $(1.63)$ & $(1.64)$ \\
\hline \multirow[t]{2}{*}{ French Legal Origin } & & & 0.047 \\
\hline & & & $(0.19)$ \\
\hline \multirow[t]{2}{*}{ German Legal Origin } & & & -0.312 \\
\hline & & & $(0.62)$ \\
\hline \multirow[t]{2}{*}{ Nordic Legal Origin } & & & 0.023 \\
\hline & & & $(0.05)$ \\
\hline Country Fixed Effects & Yes & No & No \\
\hline Observations & 623 & 623 & 623 \\
\hline R-squared & $27.1 \%$ & $13.4 \%$ & $13.6 \%$ \\
\hline
\end{tabular}

\section{Panel B: Industry average risk}

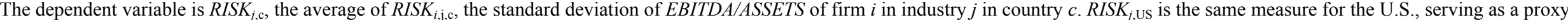

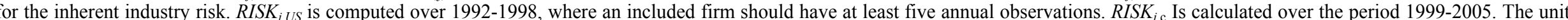
of observation is 2-digit SIC code industry. Excluded industries are as in Panel A. An included industry needs to have at least two firms with available RISK.

\section{$R_{I S K_{j, U S}}$}

CRIGHTS * RISK $K_{j, U S}$

$0.862^{* * *}$
$(4.49)$

$-0.158^{* *}$

(2.16)

$0.953^{* * *}$

(4.63)

$-0.177^{* *}$

(2.38)
$0.921^{* * *}$

(4.77)

$-0.173^{* *}$

(2.38) 


\section{CRIGHTS}

French Legal Origin

German Legal Origin

$0.012^{* * *}$

(3.01)
$0.008^{*}$

(1.92)

$-0.023^{* *}$

(2.57)

$-0.026^{* *}$

(2.77)

(0.03)

Nordic Legal Origi Observations Yes 802 $30.2 \%$

No

$$
\text { R-squared }
$$

No

802

$10.5 \%$

$10.7 \%$ 
Table 10. Recovery rates and mergers and acquisitions

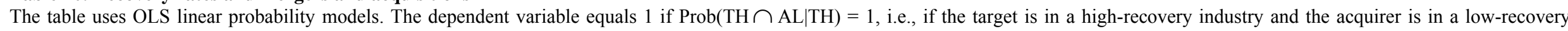

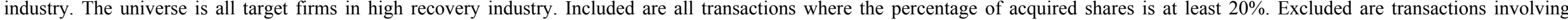

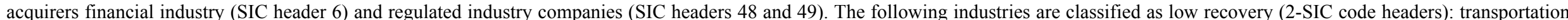

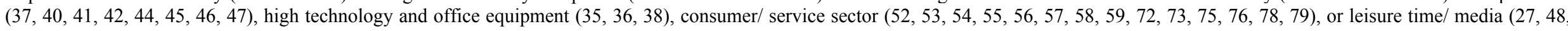

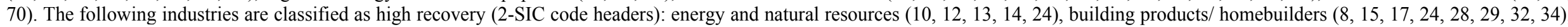

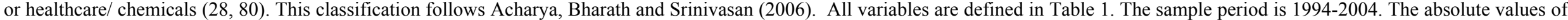

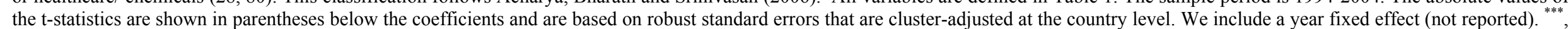
,* and ${ }^{*}$ indicate significance at the $1 \%, 5 \%$, and $10 \%$ levels, correspondingly. The table further reports the number of observations and R-squared.

\begin{tabular}{|c|c|c|c|c|c|c|c|c|c|c|}
\hline & \multicolumn{10}{|c|}{ Dependent variable $=1$ for $(\mathrm{TH} \cap \mathrm{AL} \mid \mathrm{TH})$} \\
\hline & \multicolumn{5}{|c|}{ All countries } & \multicolumn{5}{|c|}{ Excluding the U.S. } \\
\hline & $(1)$ & (2) & (3) & (4) & $(5)$ & $(6)$ & (7) & $(8)$ & (9) & $(10)$ \\
\hline CRIGHTS & $\begin{array}{c}0.021^{* * *} \\
(3.05)\end{array}$ & & & & & $\begin{array}{c}0.032^{* * *} \\
(6.64)\end{array}$ & & & & \\
\hline AUTOSTAY & & $\begin{array}{c}0.064^{* * *} \\
(3.87)\end{array}$ & & & & & $\begin{array}{c}0.074^{* * *} \\
(6.1)\end{array}$ & & & \\
\hline$R E O R G$ & & & $\begin{array}{c}0.052^{* * *} \\
(3.01)\end{array}$ & & & & & $\begin{array}{l}0.08^{* * *} \\
(6.27)\end{array}$ & & \\
\hline SECURED & & & & $\begin{array}{l}0.036 \\
(1.47)\end{array}$ & & & & & $\begin{array}{l}0.029 \\
(1.01)\end{array}$ & \\
\hline MANAGES & & & & & $\begin{array}{l}0.042^{*} \\
(1.85)\end{array}$ & & & & & $\begin{array}{c}0.093^{* * *} \\
(4.72)\end{array}$ \\
\hline SHRIGHTS & $\begin{array}{l}0.012 \\
(1.10)\end{array}$ & $\begin{array}{l}0.016 \\
(1.63)\end{array}$ & $\begin{array}{l}0.016 \\
(1.49)\end{array}$ & $\begin{array}{l}0.022 \\
(1.56)\end{array}$ & $\begin{array}{l}0.012 \\
(0.82)\end{array}$ & $\begin{array}{l}0.000 \\
(0.01)\end{array}$ & $\begin{array}{l}0.009 \\
(1.05)\end{array}$ & $\begin{array}{l}0.005 \\
(0.49)\end{array}$ & $\begin{array}{l}0.016 \\
(1.24)\end{array}$ & $\begin{array}{l}-0.009 \\
(0.77)\end{array}$ \\
\hline Rule of Law & $\begin{array}{c}-0.179^{* * *} \\
(3.81)\end{array}$ & $\begin{array}{c}-0.192^{* * *} \\
(4.43)\end{array}$ & $\begin{array}{c}-0.177^{* * *} \\
(3.69)\end{array}$ & $\begin{array}{c}-0.186^{* * *} \\
(3.71)\end{array}$ & $\begin{array}{c}-0.172^{* * *} \\
(3.39)\end{array}$ & $\begin{array}{l}-0.06^{* *} \\
(2.33)\end{array}$ & $\begin{array}{c}-0.101^{* * *} \\
(3.54)\end{array}$ & $\begin{array}{c}-0.058^{*} \\
(1.89)\end{array}$ & $\begin{array}{c}-0.101^{* * *} \\
(3.23)\end{array}$ & $\begin{array}{l}-0.023 \\
(0.69)\end{array}$ \\
\hline nch Legal Origin & $\begin{array}{c}-0.131^{* * *} \\
(2.82)\end{array}$ & $\begin{array}{c}-0.144^{* * *} \\
(3.15)\end{array}$ & $\begin{array}{c}-0.153^{* * *} \\
(3.19)\end{array}$ & $\begin{array}{c}-0.163^{* * *} \\
(2.89)\end{array}$ & $\begin{array}{c}-0.148^{* * *} \\
(2.78)\end{array}$ & $\begin{array}{c}-0.046^{*} \\
(1.71)\end{array}$ & $\begin{array}{c}-0.09^{* * *} \\
(2.66)\end{array}$ & $\begin{array}{c}-0.078^{* * *} \\
(2.85)\end{array}$ & $\begin{array}{c}-0.123^{* * *} \\
(2.96)\end{array}$ & $\begin{array}{l}-0.041 \\
(1.11)\end{array}$ \\
\hline nan Legal Origin & $\begin{array}{l}-0.002 \\
(0.07)\end{array}$ & $\begin{array}{l}0.010 \\
(0.35)\end{array}$ & $\begin{array}{l}0.019 \\
(0.63)\end{array}$ & $\begin{array}{l}0.017 \\
(0.51)\end{array}$ & $\begin{array}{l}-0.017 \\
(0.42)\end{array}$ & $\begin{array}{c}0.071^{\text {*** }} \\
(2.97)\end{array}$ & $\begin{array}{c}0.076^{* * *} \\
(2.7)\end{array}$ & $\begin{array}{c}0.102^{* * *} \\
(4.1)\end{array}$ & $\begin{array}{c}0.076^{* * *} \\
(3.09)\end{array}$ & $\begin{array}{l}0.036 \\
(1.42)\end{array}$ \\
\hline dic Legal Origin & $\begin{array}{l}0.154 \\
(1.63)\end{array}$ & $\begin{array}{c}0.17^{*} \\
(1.81)\end{array}$ & $\begin{array}{c}0.122 \\
(1.2)\end{array}$ & $\begin{array}{l}0.114 \\
(1.02)\end{array}$ & $\begin{array}{c}0.148 \\
(1.5)\end{array}$ & $\begin{array}{l}0.174^{*} \\
(1.91)\end{array}$ & $\begin{array}{l}0.178^{*} \\
(1.89)\end{array}$ & $\begin{array}{l}0.127 \\
(1.28)\end{array}$ & $\begin{array}{c}0.114 \\
(1)\end{array}$ & $\begin{array}{c}0.19^{* *} \\
(2.1)\end{array}$ \\
\hline MacroRisk & $\begin{array}{l}1.35^{* * *} \\
(3.18)\end{array}$ & $\begin{array}{c}1.379^{* * *} \\
(3.35)\end{array}$ & $\begin{array}{c}1.542^{* * *} \\
(3.62)\end{array}$ & $\begin{array}{c}2.191^{* * *} \\
(4.03)\end{array}$ & $\begin{array}{l}1.61^{* * *} \\
(3.19)\end{array}$ & $\begin{array}{l}1.25^{* * *} \\
(3.64)\end{array}$ & $\begin{array}{l}1.5^{* * *} \\
(3.96)\end{array}$ & $\begin{array}{c}1.502^{* * *} \\
(4.52)\end{array}$ & $\begin{array}{c}2.353^{* * *} \\
(4.09)\end{array}$ & $\begin{array}{c}1.252^{* * *} \\
(2.84)\end{array}$ \\
\hline
\end{tabular}




\begin{tabular}{|c|c|c|c|c|c|c|c|c|c|c|}
\hline & $(4.22)$ & $(4.52)$ & $(4.17)$ & $(4.11)$ & $(3.89)$ & $(4.03)$ & $(4.31)$ & $(3.7)$ & $(3.75)$ & $(2.42)$ \\
\hline \multirow[t]{2}{*}{ Log (Transaction Value) } & $-0.006^{* *}$ & $-0.007^{* *}$ & $-0.006^{* *}$ & $-0.007^{* *}$ & $-0.006^{* *}$ & $-0.006^{*}$ & $-0.006^{*}$ & $-0.006^{*}$ & $-0.006^{*}$ & $-0.006^{*}$ \\
\hline & $(2.18)$ & $(2.27)$ & $(2.26)$ & $(2.25)$ & $(2.06)$ & $(1.88)$ & $(1.81)$ & $(1.94)$ & $(1.79)$ & $(1.82)$ \\
\hline Ranked Medial Leverage & $-0.116^{* * *}$ & $-0.116^{* * *}$ & $-0.115^{* * *}$ & $-0.115^{* * *}$ & $-0.115^{* * *}$ & $-0.118^{* * *}$ & $-0.118^{* * *}$ & $-0.118^{* * *}$ & $-0.116^{* * *}$ & $-0.118^{* * *}$ \\
\hline For Acquirer Industry & $(7.14)$ & $(7.16)$ & $(7.11)$ & (7.13) & $(7.11)$ & $(3.68)$ & $(3.67)$ & (3.66) & (3.64) & (3.67) \\
\hline Ranked Medial Leverage & $0.106^{* * *}$ & $0.106^{* * *}$ & $0.106^{* * *}$ & $0.108^{* * *}$ & $0.106^{* * *}$ & $0.097^{* * *}$ & $0.099^{* * *}$ & $0.098^{* * *}$ & $0.103^{* * *}$ & $0.097^{* * *}$ \\
\hline For Target Industry & $(10.54)$ & $(10.77)$ & $(10.71)$ & $(10.89)$ & $(10.76)$ & $(5.2)$ & $(5.4)$ & $(5.26)$ & $(5.31)$ & $(5.19)$ \\
\hline Sample period & 1994-2004 & 1994-2004 & 1994-2004 & 1994-2004 & 1994-2004 & 1994-2004 & 1994-2004 & $1994-2004$ & 1994-2004 & 1994-2004 \\
\hline Year Fixed Effect & Yes & Yes & Yes & Yes & Yes & Yes & Yes & Yes & Yes & Yes \\
\hline Number of countries & 38 & 38 & 38 & 38 & 38 & 37 & 37 & 37 & 37 & 37 \\
\hline Observations & 6,495 & 6,495 & 6,495 & 6,495 & 6,495 & 3,356 & 3,356 & 3,356 & 3,356 & 3,356 \\
\hline R-squared & $12.3 \%$ & $12.3 \%$ & $12.3 \%$ & $12.1 \%$ & $12.2 \%$ & $17.1 \%$ & $16.8 \%$ & $17.0 \%$ & $16.0 \%$ & $17.0 \%$ \\
\hline
\end{tabular}


Figure 1. Timeline of the model.

Figure 1: Timeline of the model

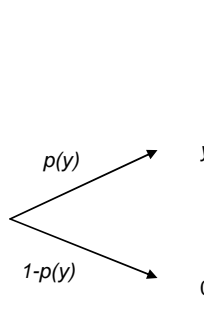

0

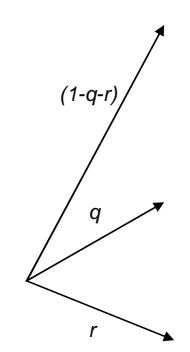

$t=1$

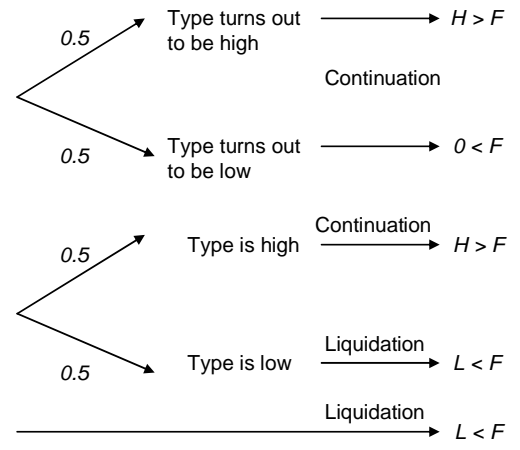

Distress and Reorganization

\begin{tabular}{ll}
\multicolumn{1}{c}{$\mathrm{t}=0$} & \multicolumn{1}{c}{$\mathrm{t}=1$} \\
$\begin{array}{l}\text { Manager chooses } \\
\text { the riskiness of the } \\
\text { leveraged firm, } y .\end{array}$ & $\begin{array}{l}\text { The firm's cashflow } \\
\text { is realised to be high } \\
\text { or low. }\end{array}$ \\
$\begin{array}{ll}\text { The firm has debt of } \\
\text { face value } F\end{array}$ & $\begin{array}{l}\text { There is default on } \\
\text { firm's debt in low } \\
\text { payable next period. }\end{array}$ \\
state.
\end{tabular}

reorganize

\begin{tabular}{|c|c|}
\hline $\begin{array}{l}\text { With probability } q \text {, } \\
\text { managerial type is } \\
\text { revealed during } \\
\text { investigation. }\end{array}$ & $\begin{array}{l}\text { With remaining } \\
\text { probability }(1-q-r) \text {, } \\
\text { management type } \\
\text { remains uncertain and } \\
\text { firm is continued. }\end{array}$ \\
\hline $\begin{array}{l}\text { If type is low (probability } \\
0.5 \text { ), the firm is efficiently } \\
\text { liquidated and } \\
\text { management suffers a } \\
\text { private cost of } m \text {. }\end{array}$ & $\begin{array}{l}\text { If type turns out to be } \\
\text { high, the output is } H \text {. } \\
\text { Otherwise, it is } O \text {. }\end{array}$ \\
\hline
\end{tabular}

type is investigated. private cost of $m$.

Otherwise, it is continued. 
Figure 2. Theil transformation of the share of same industry mergers, PROP, and creditor rights, CRIGHTS.

The fitted line represents the slope from an OLS regression of the Theil transformation of the share of same industry mergers on a constant and the creditor rights index. Note that the transformed ratio PROP may be negative.

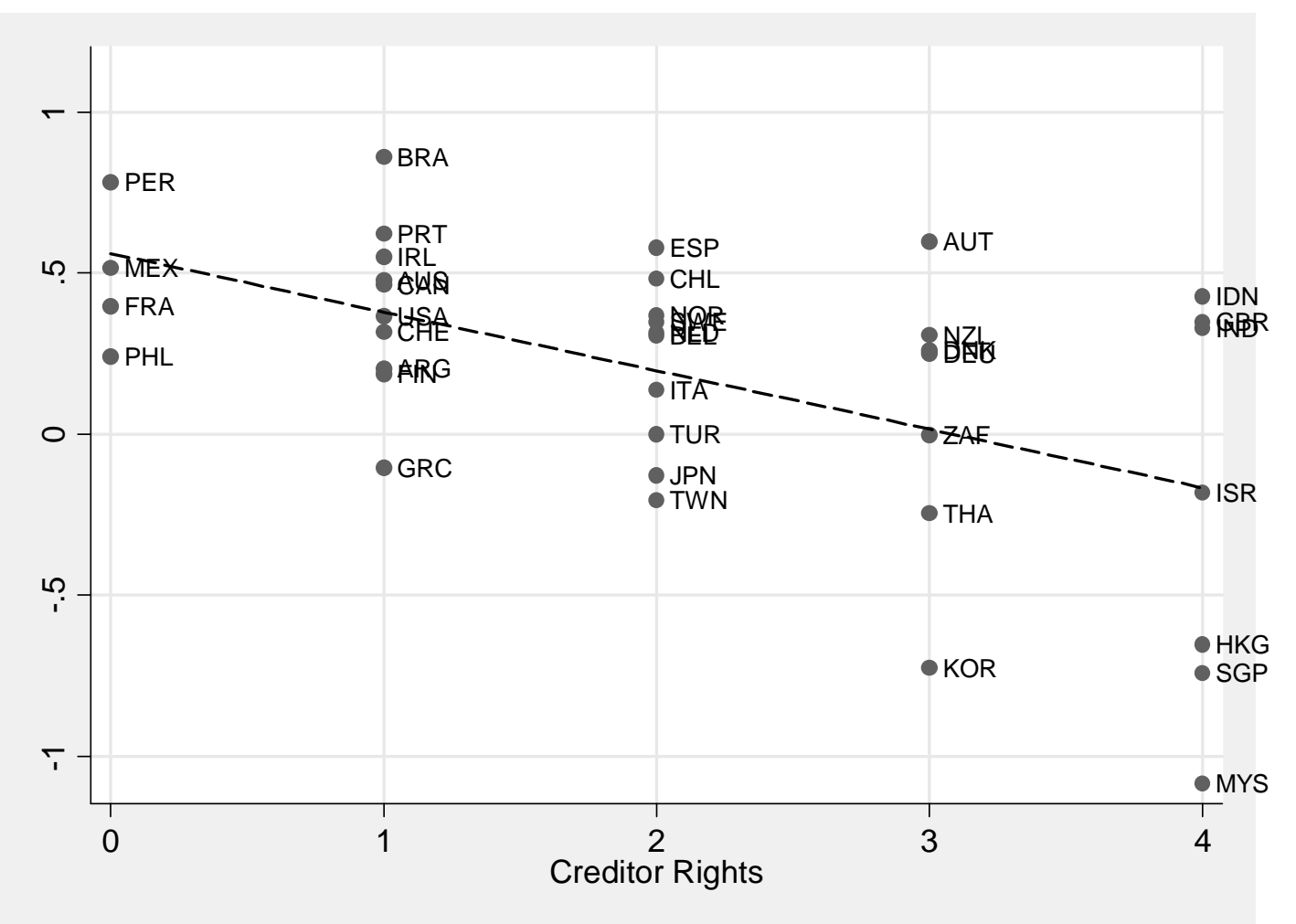

